\title{
Archetyping shared socioeconomic pathways across scales: an application to central Asia and European case studies
}

\author{
$\underline{\text { Simona Pedde }}^{1}$, Kasper Kok $^{1}$, Katharina Hölscher $^{2}$, Christoph Oberlack $^{3,4}, \underline{\text { Paula A. Harrison }}^{5}$ and Rik Leemans $^{6}$
}

\begin{abstract}
The complex interactions of drivers represented in scenarios and climate change impacts across scales have led to the development of multiscale scenarios. Since the recent development of global shared socioeconomic pathways (SSPs), which have started being downscaled to lower scales, the potential of scenarios to be relevant for decision making and facilitate appreciation and inclusion of different perspectives has been increasing, compared with a single-scale global scenario set. However, in practice, quantitative downscaling of global scenarios results in narratives that are compressed from the global level to fit the local context to enhance consistency between global and local scales. We brought forward the concept of scenario archetypes to analyze multiscale SSP scenario narratives and highlight important diverging assumptions within the same archetype. Our methodology applied scenario archetypes both as typologies, to allocate specific cases of scenarios into existing scenario archetypes, and building blocks, conceptualized with worldviews from cultural theory. Although global SSPs generally match existing archetypes and tend to be well defined, the socially unequal SSPs at subglobal scales are more nuanced, and dominant worldviews are much less straighforward to interpret than in global scenarios. The closest match was the great transition-sustainability (SSP1) archetype, whereas the most divergent was the market forcesfossil fuel development (SSP5) archetype. Overall, our results highlight the need to improve uptake of bottom-up approaches in global scenarios to improve appreciation of different perspectives as sought after in multiscale scenarios.
\end{abstract}

Key Words: multiscale scenarios; narratives; scenario archetypes; shared socioeconomic pathways; worldviews

\section{INTRODUCTION}

A key aspect to understanding the potential consequences of high-end climate change impacts is the exploration of uncertainty in long-term alternative socioeconomic futures, generally undertaken through the use of scenarios (IPCC 2014). The complex interactions of drivers represented in scenarios and climate change impacts across scales has led to the development of multiscale scenarios (Biggs et al. 2007, Kok et al. 2007). However, scenarios at subglobal scales are frequently inconsistent with global scenarios, limiting coherence in the use of multiscale scenarios (van Ruijven et al. 2014; Pedde, Clarke, Rounsevell, et al., unpublished manuscript). We utilize scenario archetypes and cultural theory to demonstrate how the archetyping of the global shared socioeconomic pathways (SSPs) along with their worldviews supports consistency in multiscale scenario development.

Multiscale analysis has evolved from its early system theory conceptualization developed in the 1980s as part of ecology hierarchy theory by Allen and colleagues (Allen and Starr 1982, Allen and Hoekstra 1992). According to this theory, components of complex systems are organized hierarchically based on multiple spatiotemporal and functional scales. Spatiotemporal linkages within socioeconomic, political, and biogeochemical systems (Gibson et al. 2000, Gallopín et al. 2001), sometimes known as "dimensions" (Vervoort et al. 2012) or levels (positions on a scale; Gibson et al. 2000, Cash et al. 2006), have also evolved in scenario exercises. Multiscale scenarios have the potential to be more relevant for decision making than single-scale global scenarios and facilitate appreciation and inclusion of different perspectives (Zurek and Henrichs 2007). However, different strengths of linkages across scales in scenarios are possible, from fully equivalent to loosely linked scenarios, depending on their desired outcome and purpose (Biggs et al. 2007, Zurek and Henrichs 2007). More precisely, the strength of the linkages depends on whether drivers and constraints from higher scales are included via downscaling (tight links) or whether they simply provide a broad conceptual framework but the overall narrative differs across scales (loose links; Biggs et al. 2007).

Multiscale scenarios, both tightly and loosely linked, tend to include stakeholder engagement to better understand impacts because of socioeconomic, political, and natural, e.g., climate and ecological, processes at different scales (Biggs et al. 2007, Kok et al. 2007). To date, the practice of multiscale scenario development often involves tight links. These links consist of quantitative downscaling of global scenarios, to define a suitable scale for impacts and vulnerability assessments. However, the subglobal scenarios often do not match the global scenarios because the scenario elements, such as narratives, assumptions, and model quantifications, were not developed to explore variations in factors relevant to impacts and vulnerability assessments (van Ruijven et al. 2014).

The new global SSPs have been developed with the aim of providing socioeconomic pathways of key socioeconomic drivers along the dimensions of challenges to mitigation and adaptation, which are scalable to different regional contexts (Kriegler et al. 2012). The global SSPs have been designed as "pathways" exploring the relevant uncertainty space of challenges to mitigation and adaptation to climate change (O'Neill et al. 2014, 2017). The design of the global SSP narratives is suitable for developing consistent cross-scale global and subglobal socioeconomic narratives (Ebi et al. 2014, O'Neill et al. 2014) because they include global-scale indicators, which are relevant to subglobal analyses (van Ruijven et al. 2014).

${ }^{1}$ Soil Geography and Landscape Group, Wageningen University and Research, Wageningen, The Netherlands, ${ }^{2}$ Dutch Research Institute for Transitions (DRIFT), ${ }^{3}$ Institute of Geography, University of Bern, Bern, Switzerland, ${ }^{4}$ Centre for Development and Environment (CDE), University of Bern, Bern, Switzerland, ${ }^{5}$ Centre for Ecology \& Hydrology, ${ }^{6}$ Environmental Systems Analysis Group, Wageningen University and Research, Wageningen, The Netherlands 
Recent examples of the application of global SSPs include subnational and subsectoral SSP narratives for the southeastern United States (Absar and Preston 2015) and Latin America (Jones and Kok 2014), coastal SSPs (Merkens et al. 2016), and more recently, deltas across West Africa and South Asia (Kebede et al. 2018) and European heat-stress SSPs (Rohat et al. 2019). These applications differ in sectoral and geographic scope but are methodologically similar in that they develop subglobal narratives that are "nested" within, i.e., are consistent with, the scenario logic of the global SSPs. One challenge with nesting scenarios is the practice of maintaining the overall global scenario logic, determined by quantitative variables, within the subglobal scenarios. The dominance of the quantitative variables in this process means that, de facto, the global SSP narratives are "compressed" from the global level to fit the local context and enhance consistency between global and local scales (Nilsson et al. 2017). In this process, narratives are reduced to single variable trends, generally classified into five categories, the so-called STEEP: society, technology, economy, environment, and policy (Hunt et al. 2012). We expand the concept of scenario "consistency" from consistency with scenario variables at the global scale to holistic consistency of the narratives that drive the logic of quantitative variables, which contain further linkages and complexity that are not captured by (modeled) quantitative variables (Rasmussen 2005).

One method for exploring consistent narratives and variables is the identification of commonalities in global-scale scenarios and grouping them into scenario families (van Vuuren et al. 2012) or archetypes (Hunt et al. 2012). Existing scenarios share common elements, i.e., similar assumptions on the trends of key variables (Hunt et al. 2012, van Vuuren et al. 2012). However, the concept of "scenario archetype" is used interchangeably with "scenario family" to indicate scenarios sharing a similar logic that translates into similar quantifications (van Vuuren et al. 2012). This loose conceptualization potentially hides subjectivity behind the transparent process of downscaling quantifications, in that the full uncertainties and meaning of the narratives are not fully explored. By linking the scenario narratives more strongly across scales using the concept of archetypes, the meaning of scenario consistency across scales can be redefined.

We develop the concept of scenario archetypes to analyze the consistency of multiscale SSP scenario narratives and the importance of diverging assumptions within the same archetype. The methodology builds on two existing approaches to analyze scenario archetypes. First, the qualitative scenario mapping of global SSPs onto existing scenario archetypes is based on a deductive approach and assesses whether SSPs can be inductively categorized within existing scenario archetypes. Second, to assess the scenario archetypes, global and subglobal SSPs are analyzed using cultural theory to systematically compare similarities and divergences and extend the discourse on archetypes to better link the global and subglobal scales. We then discuss the importance of understanding subglobal heterogeneous worldviews, typical of bottom-up approaches, to promote a holistic understanding of the concept of consistency in multiscale scenario development.

\section{METHODOLOGY}

Theoretical concepts: archetypes and scenario archetypes

The most recent analyses of scenario archetypes use the words "archetypes" and "scenario family" interchangeably. For example, scenario archetypes have been defined as those scenario families that share similar narratives or logic, which are reflected in similar types of quantifications (van Vuuren et al. 2012). Our methodology combines this definition of scenario archetypes with existing archetypal social visions on how the future might develop (Hunt et al. 2012). Crucially, such visions have been developed from scenarios at different scales and assume that existing scenarios tend to fall within archetypes (Hunt et al. 2012). Therefore, the scenario archetypes apply to both global and subglobal scenarios.

The scenario archetypes we analyze have a similar focus on narratives (as van Vuuren et al. 2012), i.e., on a qualitative analysis focusing on scenario logic. Alternatively, in sustainability research, archetypes have been analyzed as either typologies of cases or as building blocks (Oberlack et al. 2019). In the buildingblock approach, each case constitutes a combination of one or more archetypes (Eisenack 2012), whereas in the case typology approach each case is categorized into one archetype. We apply both approaches. First, global SSPs are assigned to scenario archetypes serving as a typology of cases. The cases are socioeconomic pathways, and each scenario archetype characterizes essential features of a pathway. Subsequently, we link the case typology and building block approaches through cultural theory. Specifically, we have conceptualized different worldviews as the building blocks that can belong to one or different scenario archetypes.

\section{Archetyping the global shared socioeconomic pathways as a typology of cases}

To link scenario archetypes to the SSPs, we map the global SSP narratives to established scenario archetypes. The SSPs better address challenges to mitigation and adaptation than previous scenarios such as the previous IPCC Special Report on Emission Scenarios (SRES). Compared to other scenarios, the SSPs solely focus on socioeconomic drivers and thus have the advantage of being separate from greenhouse gas emission scenarios and policy assumptions. This means that the uncertainties explored by the SSPs solely focus on socioeconomic and environmental sustainability (lifestyle, awareness, and natural resources) drivers. Because the SSPs consist of socioeconomic and environmental (but nonclimate) elements (O’Neill et al. 2017), they can be more easily mapped onto well-established archetypes of global socioeconomic and environmental scenarios (Hunt et al. 2012).

We focus on four of the five SSPs (O’Neill et al. 2017), excluding SSP2, "middle of the road," because the global SSP axis conceptualization, similar to Figure 1, locates SSP2 in the middle with intermediate challenges to mitigation and adaptation, at the intersection of the other four SSPs. SSP2 is often represented as “closest to model baseline" (Raskin 2005, O’Neill et al. 2017), and its narrative makes it challenging to define a clear identity in participatory exploratory scenario development (Kok et al. 2019). All the other SSPs (SSP1, SSP3, SSP4, and SSP5) have a clear direction, at the global level, of socioeconomic, technological, institutional, and environmental trends in SSP challenges to 
mitigation and adaptation uncertainty space. SSP1 is a sustainable scenario with effective collaboration across all actors of society; SSP3 is a socially fragmented and environmentally challenging scenario; SSP4 is a high-tech, green, and institutionally effective for a globally connected elite scenario, but with high inequality across and within society; and SSP5 is a fossil fuel, market-driven, and reduced-inequality scenario. For the full global SSP narratives, we refer to O'Neill et al. (2017), and for an overview of the European and central Asian narratives, we refer to Appendix 1.

Fig. 1. Four archetypical social visions of the world from the Global Scenario Group (adapted from Hunt et al. 2012, Raskin 2005), matched to global shared socioeconomic pathways (SSPs; O'Neill et al. 2017). SSP axes are in gray, and dotted lines indicate partly unmatched archetype. B, barbarization; GT, great transitions; MF, conventional market force; PR, conventional policy reform.

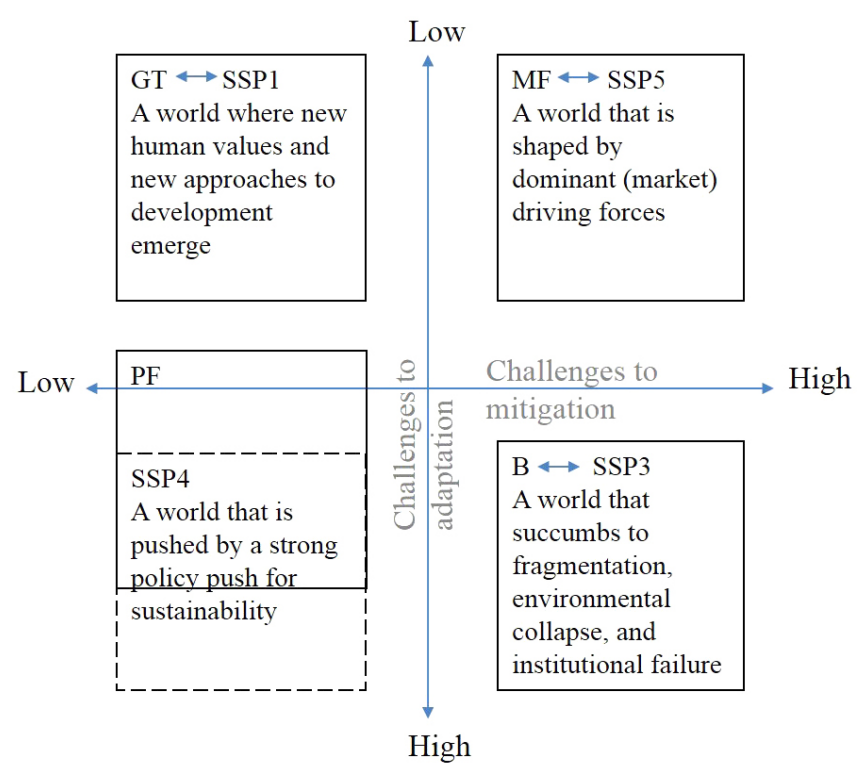

To archetype SSPs as a typology of cases, we mapped the SSP STEEP drivers onto the established global scenario archetypes produced by the Global Scenario Group (GSG) published in Raskin (2005) and subsequently tested with a $>160$ subglobal scenario subset by Hunt et al. (2012). There are four GSG archetypal social visions:

1. A world that evolves gradually as a result of market forces (market forces)

2. A world that is influenced by a strong push for sustainability (policy reform)

3. A world with novel approaches to develop new human values (great transition)

4. A fragmented world with environmental and institutional collapse (barbarization)

We first mapped the global SSPs against the GSG scenario archetypes and assessed to what extent the SSPs fit within these existing archetypes. This was undertaken qualitatively, i.e., by interpreting narratives and qualitative trends against each other. This methodology, although simple and rather subjective, is well established in the scenario literature (van Vuuren et al. 2012), especially when the narratives are limited to generic depictions of the future and take into account the same type of variables.

Second, to assess the fit of subglobal SSPs to scenario archetypes, the SSPs were analyzed across narratives at lower spatial scales. These included the pan-European scale, based on European versions of the global SSPs developed to be "equivalent" to the global SSPs and transferable across scales (Kok et al. 2019), and three geographically and culturally different regions within Europe: the Iberian Peninsula, Scotland, and two municipalities in Hungary. Finally, the archetypes were assessed at the macroregional scale for the region of central Asia, based on a set of common SSP narratives for five countries: Kazakhstan, Kyrgyzstan, Tajikistan, Turkmenistan, and Uzbekistan.

The subglobal versions of the SSPs were developed by the nesting process where the local/regional scenarios were contextualized within the larger (global) scale SSPs (Absar and Preston 2015). However, the approach for developing the European and central Asian SSPs differed from Absar and Preston (2015) in that stakeholders were involved in the development of the narratives. Stakeholders could choose the drivers for their scenario and match them afterward to the global (or European) SSP (Biggs et al. 2007, Zurek and Henrichs 2007). This has the advantage of leading to more relevant scenarios for the stakeholders, but the disadvantage of resulting in numerous narratives. This disadvantage is reduced by professionally facilitating the stakeholder scenario cocreation process (Gramberger et al. 2015).

The process in all cases resulted in subglobal, stakeholder-led scenarios developed to represent local and specific drivers nested within higher-level trends, such as internationalization, trade barriers, and so forth. The subglobal scenario narratives and driver trends are reported in the respective sections of Appendix 1. For more details on the process of developing the subglobal scenarios and stakeholder mapping, we refer to Gramberger et al. (2015).

\section{From global to local shared socioeconomic pathways, worldviews as building blocks}

Worldviews framed in cultural theory and conceptualized as building blocks were used to analyze the global and subglobal scenario narratives against the global GSG scenario archetypes. Cultural theory (Thompson et al. 1990) aims to explain how social aspects and cultural adherence determine people's worldviews. The basis of cultural theory is the grid-group typology of Douglas (1978). According to this typology, worldviews depend on the degree of freedom of individual choice as bounded by the social prescription (low or high "grid") and on the degree of involvement and solidarity among members of society (low or high "group"). According to cultural theory, thoughts about nature and other people are interwoven with worldviews and ways of life. Cultural theory identifies four worldviews (summarized in Table 1): hierarchist, egalitarian, individualist, and fatalist.

Table 1 links the four worldviews with different trends of the scenario-relevant STEEP indicators. Trends for the STEEP 
Table 1. Statements on socioeconomic, technology, economy, environment, and policy (STEEP) indicators, selected from the shared socioeconomic pathways (SSPs) scenario element. The statements are interpretations for each element according to four worldviews: hierarchist, egalitarian, individualist, and fatalist. Each statement refers to published literature, listed in the "Source" column.

\begin{tabular}{|c|c|c|c|c|c|c|}
\hline $\begin{array}{l}\text { STEEP } \\
\text { Indicator } \\
\text { (Hunt et al. } \\
\text { 2012) }\end{array}$ & $\begin{array}{l}\text { SSP Element (O'Neill et } \\
\text { al. 2017) }\end{array}$ & Hierarchist & Egalitarian & Individualist & Fatalist & Source \\
\hline \multirow[t]{3}{*}{ Society } & $\begin{array}{l}\text { Human development/ } \\
\text { equity }\end{array}$ & $\begin{array}{l}\text { Human nature is } \\
\text { ignorant and } \\
\text { therefore needs } \\
\text { education. Social } \\
\text { stability is } \\
\text { desirable, also at } \\
\text { cost of } \\
\text { maintaining } \\
\text { inequalities. }\end{array}$ & $\begin{array}{l}\text { Human nature is } \\
\text { essentially good, } \\
\text { communal, and acts } \\
\text { accordingly. Societal } \\
\text { development is the } \\
\text { driving force. Equity. }\end{array}$ & $\begin{array}{l}\text { Individual self- } \\
\text { interest and } \\
\text { material self- } \\
\text { interest are the } \\
\text { motives of action. } \\
\text { Success is personal } \\
\text { responsibility, and } \\
\text { individual } \\
\text { possibilities are the } \\
\text { driving force. }\end{array}$ & $\begin{array}{l}\text { Human nature is } \\
\text { unpredictable and } \\
\text { more hostile than } \\
\text { friendly. }\end{array}$ & $\begin{array}{l}\text { van Asselt and Rotmans } \\
(2002) \text {, Beumer and } \\
\text { Martens (2010) }\end{array}$ \\
\hline & Health investments & $\begin{array}{l}\text { Health as human } \\
\text { capital. Health } \\
\text { services. }\end{array}$ & $\begin{array}{l}\text { Health as human } \\
\text { asset. } \\
\text { Socioeconomic and } \\
\text { environmental } \\
\text { health determinants. }\end{array}$ & $\begin{array}{l}\text { Health as } \\
\text { consumption good. } \\
\text { Aging. }\end{array}$ & Unmanageable. & $\begin{array}{l}\text { van Asselt and Rotmans } \\
\text { (2002) }\end{array}$ \\
\hline & Social cohesion & $\begin{array}{l}\text { Stratification. } \\
\text { Social relations } \\
\text { based on } \\
\text { prescribed social } \\
\text { positions (high } \\
\text { group, high grid). }\end{array}$ & $\begin{array}{l}\text { High, low } \\
\text { predetermination by } \\
\text { societal position of } \\
\text { the individual (high } \\
\text { group, low grid). }\end{array}$ & $\begin{array}{l}\text { Low, but individual } \\
\text { is not limited by } \\
\text { externally imposed } \\
\text { restrictions (low } \\
\text { group, low grid). }\end{array}$ & $\begin{array}{l}\text { Low solidarity and } \\
\text { high limits to } \\
\text { individual choice } \\
\text { (low group, high } \\
\text { grid). }\end{array}$ & Thomson et al. (1990) \\
\hline Technology & Development & High technology. & $\begin{array}{l}\text { Small-scale } \\
\text { technology. }\end{array}$ & $\begin{array}{l}\text { Cheap/energy- } \\
\text { efficient } \\
\text { technology. }\end{array}$ & No preference. & $\begin{array}{l}\text { Hoekstra (1998), van } \\
\text { Asselt and Rotmans } \\
(2002)\end{array}$ \\
\hline Economy & Economic growth & $\begin{array}{l}\text { Desirable with } \\
\text { conditions. }\end{array}$ & Undesirable. & $\begin{array}{l}\text { Desirable, } \\
\text { unconditionally. }\end{array}$ & $\begin{array}{l}\text { Desirable but } \\
\text { uncontrollable. }\end{array}$ & Hoekstra (2000) \\
\hline \multirow[t]{3}{*}{ Environment } & Environment & $\begin{array}{l}\text { Nature is } \\
\text { wilderness to be } \\
\text { tamed. }\end{array}$ & $\begin{array}{l}\text { Nature is fragile and } \\
\text { wild. }\end{array}$ & $\begin{array}{l}\text { Nature is robust } \\
\text { and a resource. }\end{array}$ & $\begin{array}{l}\text { Nature is } \\
\text { capricious and } \\
\text { hazardous. }\end{array}$ & $\begin{array}{l}\text { Beumer and Martens } \\
(2010)\end{array}$ \\
\hline & $\begin{array}{l}\text { Land-use regulation/ } \\
\text { management }\end{array}$ & $\begin{array}{l}\text { Regulation. } \\
\text { Supply-oriented } \\
\text { management. } \\
\text { Medium response } \\
\text { to climate change. }\end{array}$ & $\begin{array}{l}\text { Protection. } \\
\text { Demand-oriented } \\
\text { management. High } \\
\text { response to climate } \\
\text { change. }\end{array}$ & $\begin{array}{l}\text { Adaptation. } \\
\text { Market regulation. } \\
\text { Low response to } \\
\text { climate change. }\end{array}$ & $\begin{array}{l}\text { Coping. Low } \\
\text { response to climate } \\
\text { change. }\end{array}$ & $\begin{array}{l}\text { van Asselt and Rotmans } \\
(2002) \text {, Beumer and } \\
\text { Martens (2010) }\end{array}$ \\
\hline & Agriculture & $\begin{array}{l}\text { Middle } \\
\text { productivity. } \\
\text { Food demand } \\
\text { similar to today. }\end{array}$ & $\begin{array}{l}\text { Low productivity. } \\
\text { Food demand is } \\
\text { lower because of } \\
\text { preference for } \\
\text { vegetarian diet. }\end{array}$ & $\begin{array}{l}\text { High productivity. } \\
\text { Food demand is } \\
\text { high, preference for } \\
\text { American-style } \\
\text { diet. }\end{array}$ & No policy. & $\begin{array}{l}\text { van Asselt and Rotmans } \\
\text { (2002) }\end{array}$ \\
\hline \multirow[t]{4}{*}{ Policies } & $\begin{array}{l}\text { International } \\
\text { cooperation }\end{array}$ & Controlled trade. & Limited trade. & Free trade. & $\begin{array}{l}\text { Trade is for the } \\
\text { rich. }\end{array}$ & $\begin{array}{l}\text { Hoekstra }(2000) \text {. Source } \\
\text { refers to water trade. }\end{array}$ \\
\hline & Environmental policy & $\begin{array}{l}\text { Reforestation } \\
\text { policies, } \\
\text { agricultural } \\
\text { planning. }\end{array}$ & $\begin{array}{l}\text { Ecoforestry, } \\
\text { ecoagricultural (low } \\
\text { pollutant). }\end{array}$ & $\begin{array}{l}\text { Intensive } \\
\text { agriculture, } \\
\text { protection of wood } \\
\text { sector. }\end{array}$ & $\begin{array}{l}\text { No policies/ } \\
\text { ineffective. }\end{array}$ & $\begin{array}{l}\text { van Asselt and Rotmans } \\
\text { (2002) }\end{array}$ \\
\hline & Policy orientation & Stability. & $\begin{array}{l}\text { Nature preservation/ } \\
\text { precaution. }\end{array}$ & $\begin{array}{l}\text { Growth of } \\
\text { resources. }\end{array}$ & Survival. & $\begin{array}{l}\text { Beumer and Martens } \\
\text { (2010) }\end{array}$ \\
\hline & Institutions & Control oriented. & Prevention oriented. & $\begin{array}{l}\text { Market oriented/ } \\
\text { laissez-faire. }\end{array}$ & Coping/passive. & $\begin{array}{l}\text { Hoekstra (2000), } \\
\text { Beumer and Martens } \\
(2010)\end{array}$ \\
\hline
\end{tabular}

indicators were extracted from analyses and tables published in the literature cited in Table 1 ("Source" column). The STEEP indicators for each worldview allowed us to match the worldviews, as building blocks, to each SSP. In this way, worldviews were used to compare and assess similarities and divergence across SSP narratives.
Consequently, the statements in each global and subglobal SSP narrative were matched to the STEEP indicators in Table 1 and their respective worldviews. This "coding" method (Beumer and Martens 2010), which consists of matching each global and subglobal SSP narrative statement against the STEEP indicator trends in Table 1, was applied by three experts, individually, in parallel. 
Fig. 2. Frequency count (in \%) of worldviews in the case studies: Hungary, Iberia, Scotland, Europe, and central Asia. Example from expert 1. The bottom case study is the analysis of the global sketch narratives from O’Neill et al. (2017). SSP, shared socioeconomic pathway.
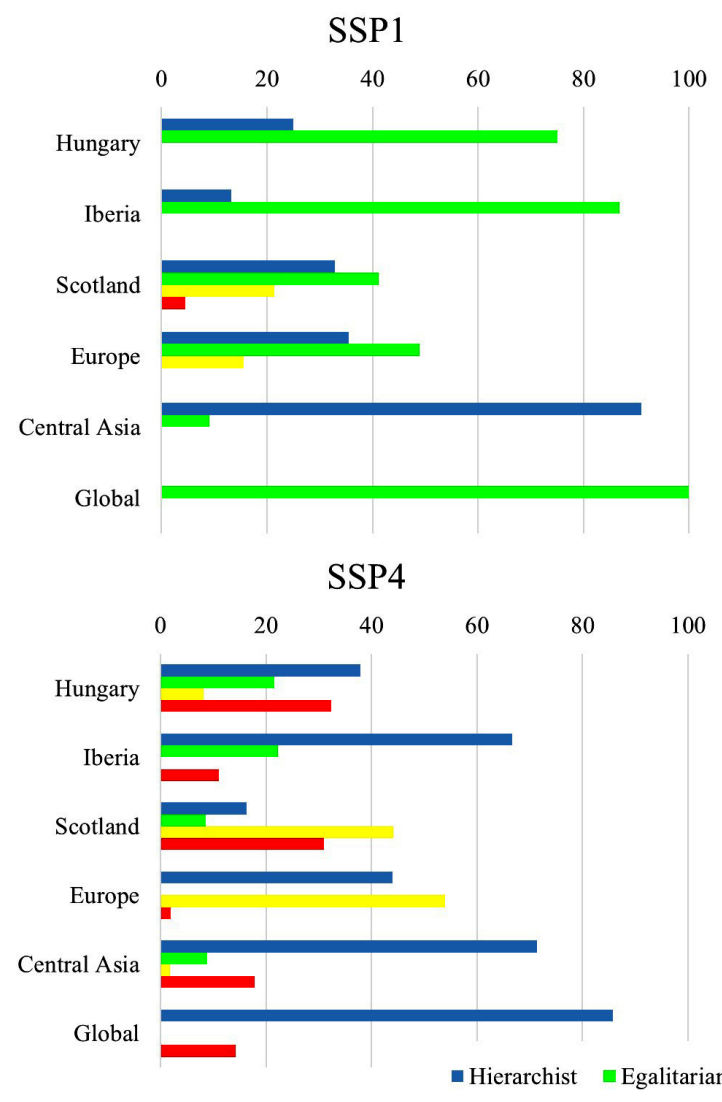
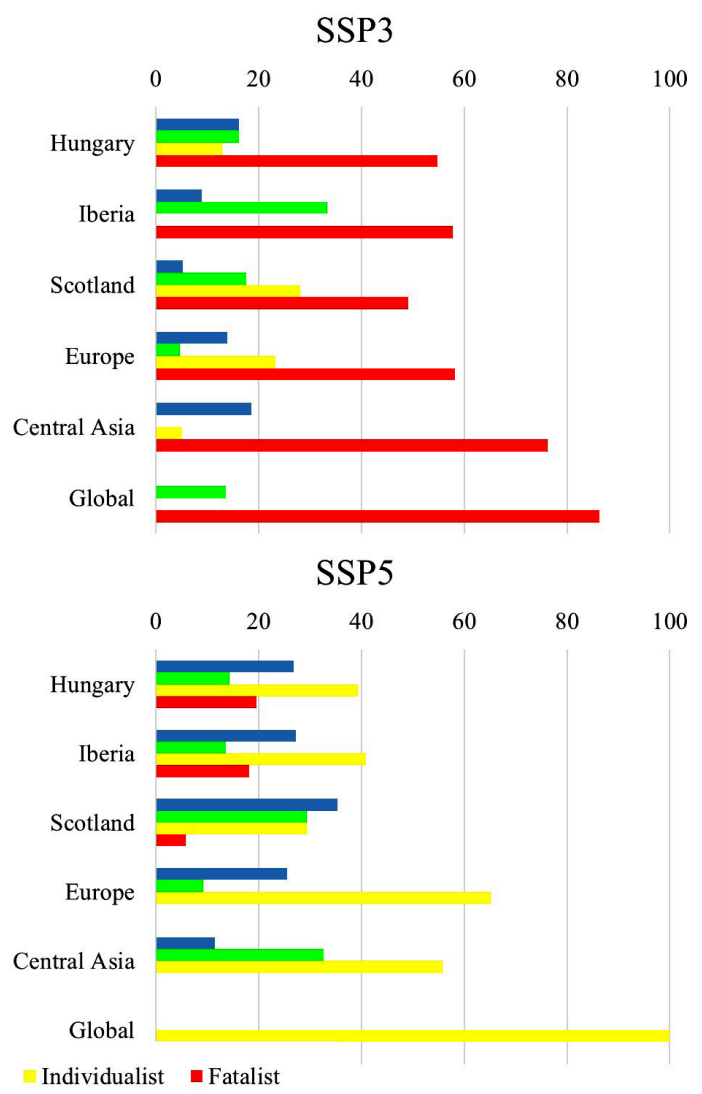

For transparency, all individual results are reported both in the Results (coding by expert 1) and Appendix 1 (coding by experts 2 and 3 ). Similarities and differences are discussed in the Results. The analysis assumes that STEEP drivers are influential at both local and global scales (Hunt et al. 2012, Wardropper et al. 2016), but local stakeholder perceptions of change may diverge from the global pathways (Wardropper et al. 2016). Cultural theory facilitates systematic interpretation of beliefs about society and nature at each scenario scale (Boschetti et al. 2016).

\section{RESULTS}

Global shared socioeconomic pathways and scenario archetypes The global SSP narratives map well onto the GSG archetypes (Fig. 1): great transitions (GT), barbarization (B), conventional policy reform (PR), and conventional market force (MF; Raskin 2005, Hunt et al. 2012). The MF scenario archetype matches most of the STEEP indicators for SSP5, with an emphasis on costeffective technological development, strong economic growth, and faith in markets rather than social and environmental policies. The only mismatch is the perception of how society changes. Although in both SSP5 and the MF archetype the emphasis is on individuals and consumerism, such trends are associated with a "worsening of society" in MF (Hunt et al. 2102), but an increase in human and social capital in SSP5 (O’Neill et al. 2017). The GT and B archetypes match in all STEEP indicators with SSP1 and SSP3, respectively: in GT and SSP1, all indicators improve, whereas in B and SSP3 all the indicators worsen. The main diverging match is between SSP4 and the PR archetype. Although they both assume strong government-led policies to achieve sustainability, the main difference is the interpretation of the effect of such a top-down policy approach in society. Whereas PR assumes that an equitable society is part of the sustainability narrative (Hunt et al. 2012), the SSP4 narrative couples green development with societal inequality and effective international cooperation aimed at, for example, climate change mitigation in a socially unequal world (O'Neill et al. 2017).

Worldviews across European scenarios

Combinations of worldviews for the five subglobal versions of each SSP are presented in Figure 2 and Appendix 1 and discussed subsequently to summarize trends across the three independent codings for each narrative and each scale. We also coded the global SSP narratives from O'Neill et al. (2017) in the last row of each quadrant in Figure 2 to compare across scales and assess divergence and similarities from the archetype typologies.

The global SSP narratives tend to be overall more homogeneous, i.e., characterized by an overall agreement on one dominant worldview for $>70 \%$ of the narratives. This is in-line with the good match between global SSP narratives and GSG archetypes 
shown in Figure 1. In SSP1 and SSP5, the worldviews are fully homogeneous, with $100 \%$ egalitarian and individualist, respectively (Fig. 2 and Appendix 1). This is in contrast with the more nuanced combinations across the other case study scales. In SSP3 and SSP4, the mix of two worldviews, fatalist and hierarchist, is more representative of the nuances of the subglobal-scale narratives.

The sustainability scenario, represented by the match between SSP1 and the GT archetype, combines an egalitarian worldview with, to a lesser extent, a hierarchist worldview in all case study scales and all time slices. Compared with all the other SSPs, SSP1 is the most homogenous scenario, in terms of worldview combinations, with the two worldviews being dominant across case studies. The egalitarian worldview is represented by statements in all scenarios on human and social development, green technology, equity, and the perception of nature as vulnerable. The Hungarian and Iberian narratives largely represent the egalitarian worldview. In the Scottish and panEuropean narratives, hierarchist elements are stronger, reflecting the combination of high-tech green development and belief in governmental regulation together with egalitarian values. Elements of individualism are also identified, related to statements on economic growth (European case study), and a focus on business and diversified economy (Scotland) and internationalization in free market economies (both Europe and Scotland).

The regionalization scenario, represented by the match between SSP3 and the B archetype, presents common traits with dominant fatalist characteristics such as a "return to a day-to-day mentality" (in Scotland) and an emphasis on surviving and coping strategies in a fragmented society. These elements are often associated with hierarchist elitist worldviews and social inequalities, and less often with the temporary environmental countermovements associated with egalitarian (Iberia and Hungary) or individualist (Europe) worldviews or both (Scotland).

SSP4, only partly matched with the PR archetype, shares characteristics of SSP1 and SSP3. On the one hand, similarly to SSP1, SSP4 contains hiearchist and egalitarian views. On the other hand, similarly to SSP3, SSP4 contains strong fatalist and hierarchist worldviews. Overall, SSP4 across case studies contains a mix of these combinations: for instance, hierarchist and individualist in Europe; hierarchist and fatalist in Iberia; hierarchist-individualist, individualist-fatalist, and fatalistegalitarian in Scotland; and hierarchist-individualist and fatalistegalitarian in Hungary. The fatalist-hierarchist and fatalistegalitarian combinations are dominant and visible in all local case studies as a result of perceived top-down enforcement and strongly hierarchist governance components. Interestingly, this combination is less visible in the European case study, where only the hierarchist component emerged more strongly with individualist elements.

Finally, SSP5 is very heterogeneous. A strong individualist perspective is present in the European case study, hiearchist and individualist are both dominant in Scotland, and in the Hungarian and Iberian case studies, individualist and hierarchist perspectives shift to egalitarian and fatalist perspectives in the later time slices.
Generally, the interpretation of the narratives, combinations of worldviews, and governance emerging from the SSP narrative analysis are consistent with cultural theory (Wildavsky 2018). The egalitarian/hiearchist combination, which emerged from SSP1, corresponds to the social democracy model, which is the closest option among those available to the participatory forms of governance sought in the SSP1 narratives. The fatalist/ individualist and hierarchist/individualist combinations, emerging from SSP3 and in some cases SSP5, are associated with state capitalism, which corresponds to the power of a few actors and weak governments. Fatalist/hierarchist, emerging from most of the SSP4 narratives, is typical of totalitarianism, which is close to the top-down, repressive governments of SSP4. Finally, the association of individualism/egalitarianism corresponds to the American individualist belief that equal opportunity leads to equal results (Wildavsky 2018). This combination is less visible, and only partly identified in the European and Scottish SSP1.

Overall, the results highlight that the global scenarios SSP4 and SSP3, characterized by social inequality, are more nuanced, at the subglobal scale, than the SSP1 archetypes (GT). Although, globally, the GT, B, and MF archetypes tend to match well (Fig. 1) according to the STEEP analysis, the dominant worldviews and combinations are not as straightforward across subglobal SSPs. The disagreement on associations between the individualist and other worldviews in SSP5 is visible in the different interpretations of the scenarios across scales (Fig. 2). The expert coding also resulted in larger disagreement on the interpretation for SSP5 than for other scenarios (Appendix 1).

\section{DISCUSSION}

Toward consistency of scenarios: archetyping shared socioeconomic pathways across scales

We assessed the consistency of SSPs with the GSG scenario archetypes across multiple scales from global to local, in two ways. First, we related the global SSPs with the scenario archetypes (Hunt et al. 2012). The results show a good match between the two, with only a few deviations. Second, we analyzed both the global and the subglobal versions of SSPs from the perspective of worldviews, to compare deviations across different combinations of worldviews in scenarios within the same archetype. The analysis of worldviews embodied in scenario archetypes has highlighted sources of inconsistencies in scenarios across scales. The divergence of SSP narratives within the same archetype is because of differences in worldviews within local characteristics rather than considerations of internal consistency (Hunt et al. 2012, Price et al. 2014) or modeling framework requirements (Kebede et al. 2015).

Consistency of scenario archetypes across scales can be strengthened by developing scenarios in a bottom-up manner to match global archetypes, i.e., by using and refining global scenario archetypes in contextualized scenario development. Examples include archetypal scenarios of the Anthropocene in southern Africa through transformative visioning (Pereira et al. 2018), as well as the case of a regional watershed scenario project in Wisconsin, USA, where local perspectives on how change occurs were used to emphasize and contextualize three global archetypes (Wardropper et al. 2016). Unlike the latter study, ours focuses on scenarios understood as exploratory futures. 


\section{Limitations and benefits of the applied approach}

Our study has several limitations. First, the coding of the global and subglobal SSP narratives against the STEEP indicators is subject to interpretation (e.g., van Vuuren et al. 2012). To minimize this, we selected experts that were familiar with the SSP narratives and cultural theory and that would have a similar understanding of both. This, therefore, limited the number of experts to a small subset of the author team rather than a larger coding team. Second, through choosing cultural theory, our analyses were limited to four worldviews, but a larger number of worldviews may be more realistic (Pahl-Wostl et al. 2008). Third, the building blocks in Table 1 were selected based on available information in the existing literature. These decisions were made because a choice had to be made between enriching Table 1 with additional categories, fully based on interpretation, or excluding important information from the SSP narrative coding. To limit additional interpretation, we chose the latter option. As a consequence, key SSP uncertainties could not be categorized into the four worldviews. For example, key SSP uncertainties relating to international cooperation and population growth could not be attributed to a specific worldview and were therefore excluded from the coding. This had an impact on the final composition of the narrative building blocks. It was, however, not our aim to quantify the exact composition of the worldviews in the narratives, but rather to analyze emerging patterns across SSPs. Additionally, most SSP trends could be reflected using the elements in Table 1, and therefore, the coding resulted in a reasonable representation of the overall narrative for each SSP. In spite of its limited categories, cultural theory is a well-known approach in scenario analysis that combines environmental modeling with social-science-based analysis. The availability of extensive applications of cultural theory in previous studies meant that it was possible to extract the statements in Table 1 directly from existing scenario literature, with little additional interpretation.

A further consequence of limiting the statements in Table 1 is that some SSP statements may overlap or partly mismatch with multiple worldviews. For example, the "environmentally carefree" statements in most SSP5 narratives could be attributed to either fatalist or individualist worldviews and relate to the (subjective) interpretation of strong economic development and the meaning of governmental investment. Therefore, coding diverged most for SSP5 and least for SSP1. Such divergence may also indicate that SSP5 is less homogenous, especially at the subglobal scale.

In addition, there is an inevitable bias because of the participatory and more bottom-up approach used to develop the SSP narratives in Europe and central Asia. This results from the focus on the narratives, which drove the coding, especially in SSP3 and SSP4. For example, in the same narrative, the coding might change if it considered different parts of the society, e.g., if the focus was separately on elites (interpreted as hierarchist or individualist) or the poor (generally fatalist, but also egalitarian when proactive). The repeated mention of strong government, or lack of it, has an effect on the proportion of the hierarchist worldview within the same case study: hierarchist worldviews are comparatively strong in SSP1 and SSP5 for Scotland among all case studies we assessed, and lowest in the Scottish SSP3 and SSP4. However, this bias also suggests different worldviews in the local case studies, which could be more directly linked to the personal and cultural background of the stakeholders who created the narratives. This is potentially a useful attribute, particularly if the SSP narratives are utilized to identify challenges and opportunities to address environmental problems robustly across SSPs.

\section{Contextual aspects}

In this way, the heterogeneity of worldviews shows that the same SSP across scales potentially accounts for different regional contexts in the variation of worldviews and that cultural theory can structure the analysis of archetypes to link worldviews in SSPs across scales. For instance, policy development based on scenarios with strong individualist worldviews is less likely to succeed in countries with strong egalitarian values (Corner et al. 2014). The contextual aspects can be identified also within the most homogeneous SSP1. For example, the central Asian SSP1 narrative is more focused on a stronger government intervention to drive sustainability compared with the European (and global) SSP1. These differences also indicate that obvious and simple relations across socioeconomic and, consequently, other STEEP variables, identified at the global scale, should be carefully interpreted both in multiscale scenario development and quantitative impact analyses, and that cultural theory can complement STEEP variable interpretation. The analysis also showed that more detailed narratives, such as the Scottish SSPs, are characterized by more realism, which resulted in a more nuanced mix of worldviews for each of the European and central Asian SSP narratives, in contrast to the simple global SSP narratives.

The combination of two archetype approaches, framing archetypes as a typology of cases (the GSG scenario archetypes) and building blocks (the worldviews), demonstrates their complementarity. The narratives and the multiple worldviews in subglobal SSPs show, for example, the nuances within the same archeytpe that would not be captured by matching SSPs only as a typology of cases with a priori archeytpes using STEEP drivers. For instance, our results show that even the most homogenous GT archetype does not consist of only egalitarian worldviews, as in the global SSP1 narratives, but also of hierarchist and individualist worldviews, as in the European and central Asian SSP1 narratives.

\section{Relating scenario archetypes to other archetype analyses in sustainability research}

In sustainability research, archetypes have been used for pattern identification, with nuanced meanings and different research practices (Oberlack et al. 2019). Pattern-identifying studies reveal archetypes inductively by using comparative or statistical methods for analyses of empirical data (Oberlack et al. 2016, Sietz et al. 2017, Levers et al. 2018). Archetypes function as diagnostic tools, if well-established knowledge on archetypes is used to diagnose the system of concern or assess hypothesized causal effects in new empirical research (Banson et al. 2016, Mokhtar and Aram 2017). In both functions, archetypes refer to empirically validated, recurrent patterns of the phenomenon of interest (Eisenack et al. 2006).

Scenario archetypes, by contrast, refer to a set of internally consistent scenarios with common narratives and characteristics, often developed with stakeholder engagement in futures research (Hunt et al. 2012). We have identified scenario archetypes as 
having similar diagnosis and pattern identification functions as archetypes in sustainability research because well-established archetypes guide empirical analysis and can, in turn, serve as diagnostic tools to test understanding of the system. Better interplay of these strands of archetype research could strengthen the knowledge claims embodied in archetypes in at least two ways. First, scenario archetypes could help frame the research questions of interest for empirical and diagnostic sustainability archetype research. Second, empirical archetype analyses could help validate the causal effects or mechanisms assumed in scenario archetypes.

\section{CONCLUSIONS}

We illustrate that existing scenario archetypes are relevant for assessing scenario narratives developed across multiple scales. Furthermore, it shows that different archetype approaches can be conceptually connected, such as through using scenario archetypes as a typology of cases, which is then further interpreted using worldviews as building blocks. The analysis demonstrates that existing scenario archetypes relate to global SSP narratives sufficiently to conceptualize scenarios as a typology of cases. The analysis of cultural theory with worldviews as archetype building blocks reveals patterns, which strengthen the scenario typology, but also important divergences, which highlight the importance of including contextual knowledge and allowing for variance, such as in the SSP5 narratives. Scenario narratives have been employed to capture complexities at multiple scales and to complement the STEEP approach based on driver trends. These findings can guide future bottom-up adoption and development of global SSP narratives at subglobal scales to better capture different contexts and emerging patterns.

\section{Responses to this article can be read online at: http://www.ecologyandsociety.org/issues/responses. php/11241}

\section{Acknowledgments:}

The research was financially supported by the IMPRESSIONS project, funded by the European Union's Seventh Framework Programme for research, technological development, and demonstration under Grant Agreement Number 603416. We are very thankful to the IMPRESSIONS colleagues and stakeholders who participated in the codevelopment of the scenario narratives during stakeholder workshops and to two anonymous reviewers for their very constructive comments.

\section{LITERATURE CITED}

Absar, S. M., and B. L. Preston. 2015. Extending the shared socioeconomic pathways for sub-national impacts, adaptation, and vulnerability studies. Global Environmental Change 33:83-96. https://doi.org/10.1016/j.gloenvcha.2015.04.004

Allen, T. F. H., and T. W. Hoekstra. 1992. Toward a unified ecology. Columbia University Press, New York, New York, USA.

Allen, T. F. H., and T. B. Starr. 1982. Hierarchy perspectives for ecological complexity. University of Chicago Press, Chicago, Illinois, USA.
Banson, K. E., N. C. Nguyen, and O. J. H. Bosch. 2016. Using system archetypes to identify drivers and barriers for sustainable agriculture in Africa: a case study in Ghana. Systems Research and Behavioral Science 33:79-99. https://doi.org/10.1002/ sres. 2300

Beumer, C., and P. Martens. 2010. Noah's Ark or World Wild Web? Cultural perspectives in global scenario studies and their function for biodiversity conservation in a changing world. Sustainability 2:3211-3238. https://doi.org/10.3390/su2103211

Biggs, R., C. Raudsepp-Hearne, C. Atkinson-Palombo, E. Bohensky, E. Boyd, G. Cundill, H. Fox, S. Ingram, K. Kok, S. Spehar, M. Tengö, D. Timmer, and M. Zurek. 2007. Linking futures across scales: a dialog on multiscale scenarios. Ecology and Society 12(1):17. https://doi.org/10.5751/ES-02051-120117

Boschetti, F., J. Price, and I. Walker. 2016. Myths of the future and scenario archetypes. Technological Forecasting and Social Change 111:76-85. https://doi.org/10.1016/j.techfore.2016.06.009

Cash, D. W., W. N. Adger, F. Berkes, P. Garden, L. Lebel, P. Olsson, L. Pritchard, and O. Young. 2006. Scale and cross-scale dynamics: governance and information in a multilevel world. Ecology and Society 11(2):8. https://doi.org/10.5751/ES-01759-110208

Corner, A., E. Markowitz, and N. Pidgeon. 2014. Public engagement with climate change: the role of human values. Wiley Interdisciplinary Reviews: Climate Change 5:411-422. https://doi. org/10.1002/wcc.269

Douglas, M. 1978. Cultural bias. Royal Anthropological Institute, London, UK.

Ebi, K. L., S. Hallegatte, T. Kram, N. W. Arnell, T. R. Carter, J. Edmonds, E. Kriegler, R. Mathur, B. C. O'Neill, K. Riahi, H. Winkler, D. P. Van Vuuren, and T. Zwickel. 2014. A new scenario framework for climate change research: background, process, and future directions. Climatic Change 122:363-372. https://doi. org/10.1007/s10584-013-0912-3

Eisenack, K. 2012. Archetypes of adaptation to climate change. Pages 107-122 in M. Glaser, G. Krause, B. M. W. Ratter, and M. Welp, editors. Human-nature interactions in the Anthropocene: potentials of social-ecological systems analysis. Routledge, New York, New York, USA.

Eisenack, K., M. Lüdeke, and J. Kropp. 2006. Construction of archetypes as a formal method to analyze social-ecological systems. In IDGEC Synthesis Conference of the Institutional Dimensions of Global Environmental Change (Bali, Indonesia, 6-9 December 2006). International Human Dimensions Programme of Global Environmental Change, Bonn, Germany. [online] URL: https://uol.de/fileadmin/user_upload/wire/fachgebiete/envdev/ download/arch-eisenack3.pdf

Gallopín, G. C., S. Funtowicz, M. O’Connor, and J. Ravetz. 2001. Science for the twenty-first century: from social contract to the scientific core. International Social Science Journal 53:219-229. https://doi.org/10.1111/1468-2451.00311

Gibson, C. C., E. Ostrom, and T. K. Ahn. 2000. The concept of scale and the human dimensions of global change: a survey. Ecological Economics 32:217-239. https://doi.org/10.1016/ $\underline{\text { S0921-8009(99)00092-0 }}$ 
Gramberger, M., K. Zellmer, K. Kok, and M. J. Metzger. 2015. Stakeholder integrated research (STIR): a new approach tested in climate change adaptation research. Climatic Change 128:201-214. https://doi.org/10.1007/s10584-014-1225-X

Hoekstra, A. Y. 1998. Perspectives on water: an integrated modelbased exploration of the future. International Books, Utrecht, The Netherlands.

Hoekstra, A. Y. 2000. Appreciation of water: four perspectives. Water Policy 1(6):605-622. https://doi.org/10.1016/S1366-7017 (99)00013-6

Hunt, D. V. L., D. R. Lombardi, S. Atkinson, A. R. G. Barber, M. Barnes, C. T. Boyko, J. Brown, J. Bryson, D. Butler, S. Caputo, M. Caserio, R. Coles, R. F. D. Cooper, R. Farmani, M. Gaterell, J. Hale, C. Hales, C. N. Hewitt, L. Jankovic, I. Jefferson, J. Leach, A. R. MacKenzie, F. A. Memon, J. P. Sadler, C. Weingaertner, J. D. Whyatt, and C. D. F. Rogers. 2012. Scenario archetypes: converging rather than diverging themes. Sustainability 4:740-772. https://doi.org/10.3390/su4040740

IPCC. 2014. Climate change 2014: impacts, adaptation, and vulnerability. Part A: global and sectoral aspects. Contribution of Working Group II to the Fifth Assessment Report of the Intergovernmental Panel on Climate Change. Cambridge University Press, Cambridge, UK.

Jones, L., and K. Kok. 2014. Scenarios for use in ROBIN (Deliverable 2.3.1.). NERC (Natural Environment Research Council), Swindon, UK.

Kebede, A. S., R. Dunford, M. Mokrech, E. Audsley, P. A. Harrison, I. P. Holman, R. J. Nicholls, S. Rickebusch, M. D. A. Rounsevell, S. Sabaté, F. Sallaba, A. Sanchez, C. Savin, M. Trnka, and F. Wimmer. 2015. Direct and indirect impacts of climate and socio-economic change in Europe: a sensitivity analysis for key land- and water-based sectors. Climatic Change 128:261-277. https://doi.org/10.1007/s10584-014-1313-y

Kebede, A. S., R. J. Nicholls, A. Allan, I. Arto, I. Cazcarro, J. A. Fernandes, C. T. Hill, C. W. Hutton, S. Kay, A. N. Lázár, I. Macadam, M. Palmer, N. Suckall, E. L. Tompkins, K. Vincent, and P. W. Whitehead. 2018. Applying the global RCP-SSP-SPA scenario framework at sub-national scale: a multi-scale and participatory scenario approach. Science of the Total Environment 635:659-672. https://doi.org/10.1016/j.scitotenv.2018.03.368

Kok, K., R. Biggs, and M. Zurek. 2007. Methods for developing multiscale participatory scenarios: insights from southern Africa and Europe. Ecology and Society 13(1):8. https://doi.org/10.5751/ ES-01971-120108

Kok, K., S. Pedde, M. Gramberger, P. A. Harrison, and I. P. Holman. 2019. New European socio-economic scenarios for climate change research: operationalising concepts to extend the shared socio-economic pathways. Regional Environmental Change 19:643-654. https://doi.org/10.1007/s10113-018-1400-0

Kriegler, E., B. C. O’Neill, S. Hallegatte, T. Kram, R. J. Lempert, R. H. Moss, and T. Wilbanks. 2012. The need for and use of socioeconomic scenarios for climate change analysis: a new approach based on shared socio-economic pathways. Global Environmental Change 22:807-822. https://doi.org/10.1016/j.gloenvcha.2012.05.005
Levers, C., D. Müller, K. Erb, H. Haberl, M. R. Jepsen, M. J. Metzger, P. Meyfroidt, T. Plieninger, C. Plutzar, J. Stürck, P. H. Verburg, P. J. Verkerk, and T. Kuemmerle. 2018. Archetypical patterns and trajectories of land systems in Europe. Regional Environmental Change 18:715-732. https://doi.org/10.1007/ s10113-015-0907-X

Merkens, J.-L., L. Reimann, J. Hinkel, and A. T. Vafeidis. 2016. Gridded population projections for the coastal zone under the shared socioeconomic pathways. Global and Planetary Change 145:57-66. https://doi.org/10.1016/j.gloplacha.2016.08.009

Mokhtar, A., and S. Aram. 2017. Systemic insights into agricultural groundwater management: case of Firuzabad Plain, Iran. Water Policy 19:867-885. https://doi.org/10.2166/wp.2017.159

Nilsson, A. E., I. Bay-Larsen, H. Carlsen, B. van Oort, M. Bjørkan, K. Jylhä, E. Klyuchnikova, V. Masloboev, and L.-M. van der Watt. 2017. Towards extended shared socioeconomic pathways: a combined participatory bottom-up and top-down methodology with results from the Barents region. Global Environmental Change 45:124-132. https://doi.org/10.1016/j. gloenvcha.2017.06.001

Oberlack, C., D. Sietz, E. Bürgi Bonanomi, A. De Brémond, J. Dell'Angelo, K. Eisenack, E. C. Ellis, G. Epstein, M. Giger, A. Heinimann, C. Kimmich, M. T. J. Kok, D. Manuel-Navarrete, P. Messerli, P. Meyfroidt, T. Václavík, and S. Villamayor-Tomas. 2019. Archetype analysis in sustainability research: meanings, motivations, and evidence-based policy making. Ecology and Society 24(2):26. https://doi.org/10.5751/ES-10747-240226

Oberlack, C., L. Tejada, P. Messerli, S. Rist, and M. Giger. 2016. Sustainable livelihoods in the global land rush? Archetypes of livelihood vulnerability and sustainability potentials. Global Environmental Change 41:153-171. https://doi.org/10.1016/j. gloenvcha.2016.10.001

O’Neill, B. C., E. Kriegler, K. L. Ebi, E. Kemp-Benedict, K. Riahi, D. S. Rothman, B. J. van Ruijven, D. P. van Vuuren, J. Birkmann, K. Kok, M. Levy, and W. Solecki. 2017. The roads ahead: narratives for shared socioeconomic pathways describing world futures in the 21 st century. Global Environmental Change 42:169-180. https://doi.org/10.1016/j.gloenvcha.2015.01.004

O’Neill, B. C., E. Kriegler, K. Riahi, K. L. Ebi, S. Hallegatte, T. R. Carter, R. Mathur, and D. P. van Vuuren. 2014. A new scenario framework for climate change research: the concept of shared socioeconomic pathways. Climatic Change 122:387-400. https:// doi.org/10.1007/s10584-013-0905-2

Pahl-Wostl, C., D. Tàbara, R. Bouwen, M. Craps, A. Dewulf, E. Mostert, D. Ridder, and T. Taillieu. 2008. The importance of social learning and culture for sustainable water management. Ecological Economics 64:484-495. https://doi.org/10.1016/j. ecolecon.2007.08.007

Pereira, L. M., T. Hichert, M. Hamann, R. Preiser, and R. Biggs. 2018. Using futures methods to create transformative spaces: visions of a good Anthropocene in southern Africa. Ecology and Society 23(1):19. https://doi.org/10.5751/ES-09907-230119

Price, J. C., I. A. Walker, and F. Boschetti. 2014. Measuring cultural values and beliefs about environment to identify their role in climate change responses. Journal of Environmental Psychology 37:8-20. https://doi.org/10.1016/i.jenvp.2013.10.001 
Raskin, P. 2005. Global scenarios in historical perspective. Pages 35-44 in Millennium Ecosystem Assessment, editor. Ecosystems and human well-being: scenarios. Island, Washington, D.C., USA.

Rasmussen, L. B. 2005. The narrative aspect of scenario building - how story telling may give people a memory of the future. $A I \&$ SOCIET Y 19:229-249. https://doi.org/10.1007/s00146-005-0337-2

Rohat, G., J. Flacke, A. Dosio, S. Pedde, H. Dao, and M. van Maarseveen. 2019. Influence of changes in socioeconomic and climatic conditions on future heat-related health challenges in Europe. Global and Planetary Change 172:45-59. https://doi. org/10.1016/j.gloplacha.2018.09.013

Sietz, D., J. Ordoñez, M. T. J. Kok, P. Janssen, H. B. M. Hilderink, P. Tittonell, and H. Van Dijk. 2017. Nested archetypes of vulnerability in African drylands: where lies potential for sustainable agricultural intensification? Environmental Research Letters 12:095006. https://doi.org/10.1088/1748-9326/aa768b

Thompson, M., R. Ellis, and A. Wildavsky. 1990. Cultural theory. Westview, Boulder, Colorado, USA.

van Asselt, M. B. A., and J. Rotmans. 2002. Uncertainty in integrated assessment modelling. Climatic Change 54(1):75-105. https://doi.org/10.1023/A:1015783803445

van Ruijven, B. J., M. A. Levy, A. Agrawal, F. Biermann, J. Birkmann, T. R. Carter, K. L. Ebi, M. Garschagen, B. Jones, R. Jones, E. Kemp-Benedict, M. Kok, K. Kok, M. C. Lemos, P. L. Lucas, B. Orlove, S. Pachauri, T. M. Parris, A. Patwardhan, A. Petersen, B. L. Preston, J. Ribot, D. S. Rothman, and V. J. Schweizer. 2014. Enhancing the relevance of shared socioeconomic pathways for climate change impacts, adaptation and vulnerability research. Climatic Change 122:481-494. https:// doi.org/10.1007/s10584-013-0931-0

van Vuuren, D. P., M. T. J. Kok, B. Girod, P. L. Lucas, and B. de Vries. 2012. Scenarios in global environmental assessments: key characteristics and lessons for future use. Global Environmental Change 22:884-895. https://doi.org/10.1016/j.gloenvcha.2012.06.001

Vervoort, J. M., L. Rutting, K. Kok, F. L. P. Hermans, T. Veldkamp, A. K. Bregt, and R. van Lammeren. 2012. Exploring dimensions, scales, and cross-scale dynamics from the perspectives of change agents in social-ecological systems. Ecology and Society 17(4):24. https://doi.org/10.5751/ES-05098-170424

Wardropper, C. B., S. Gillon, A. S. Mase, E. A. McKinney, S. R. Carpenter, and A. R. Rissman. 2016. Local perspectives and global archetypes in scenario development. Ecology and Society 21(2):12. https://doi.org/10.5751/ES-08384-210212

Wildavsky, A. 2018. Cultural analysis. Volume 1, politics, public law, and administration. Routledge, New York, New York, USA. https://doi.org/10.4324/9780203794234

Zurek, M. B., and T. Henrichs. 2007. Linking scenarios across geographical scales in international environmental assessments. Technological Forecasting and Social Change 74:1282-1295. https://doi.org/10.1016/j.techfore.2006.11.005 
Appendix 1. Archetyping shared socioeconomic pathways across scales: an application to central Asia and European case studies.

\section{Methodology: Process to develop participatory European SSPs (Eur-SSPs) and local European SSPs}

For full stakeholder engagement methodology, we refer to Gramberger et al. (2015)

Stakeholder selection

A list of selection criteria were put in place to balance and broaden the different societal stakeholders' opinions and while ensure scientific credibility and societal relevance. The first criterion was to cover the relevant sectors in all case studies. The key sectors were identified within the region to include both the local specific context and enough generalization to ensure consistency across case studies. Next to a few generally agreed sectors - infrastructure, water, energy, finance/insurance - there were also a number of sectors that are unique to a smaller number of case studies or even unique to one. These were, for example, agriculture, food \& nutrition, whisky, forestry, biodiversity conservation and tourism.

The second criterion was to cover the individual and professional geographical scope of activity of participants and respective organizations. The geographical criterion was multilevel and includes municipal/local, regional, national, European and international levels.

The third criterion included individual characteristics, such as age, sex and function.

The final selection of criteria for each case study are reported in Table A1. In total the following numbers of individuals could be identified per case study: - Central Asia: 54 individuals • Europe: 77 individuals • Scotland: 39 individuals • Iberia: 67 individuals • Hungary: 74 individuals. The difference in number was due to the different set-up as well as the different level of evolution of the case studies. The Scottish case study, for example, could build on a dense stakeholder network that has been working with the project partners in the past and had already indicated their commitment to participating in the workshops.

\section{Stakeholders attendance}

Due to process design and budget limitations, a small number of participants attended each workshop (between 20 and 25 participants). This restriction introduced a key methodological challenge for stakeholder selection, because the main objective of was be inclusiveness of different views and perspectives and avoid overrepresentation of certain typologies of stakeholders and sectors. These challenges were overcome by adding quotas to each criterion. Whereas quota for general criteria are the same in all case studies, i.e. $30 \%$ of male and female participants per workshop, other quota differ amongst case studies depending on the relevance of the criterion. For example, the relevance and quota of the sector "energy" compared to other sectors was different in each case study. All criteria were fulfilled during the invitation process, although, finally, only 4 out of 143 quota were not fulfilled, mainly relating to last minute cancellations.

Table A1: overview of stakeholder selection criteria for each case study

\begin{tabular}{|l|l|l|l|l|l|}
\hline Case study & $\begin{array}{l}\text { Central } \\
\text { Asia }\end{array}$ & Europe & Scotland & Iberia & Hungary \\
\hline Organizational affiliation & $\mathrm{x}$ & $\mathrm{x}$ & $\mathrm{x}$ & $\mathrm{x}$ & $\mathrm{x}$ \\
\hline - Government & $\mathrm{x}$ &
\end{tabular}




\begin{tabular}{|c|c|c|c|c|c|}
\hline - Economy/Enterprise & $\mathrm{x}$ & $\mathrm{x}$ & $\mathrm{x}$ & $\mathrm{x}$ & $\mathrm{X}$ \\
\hline - Civil society & $\mathrm{X}$ & $\mathrm{x}$ & $\mathrm{X}$ & $\mathrm{X}$ & $\mathrm{x}$ \\
\hline - Research & $\mathrm{X}$ & $\mathrm{x}$ & $\mathrm{x}$ & $\mathrm{X}$ & $\mathrm{x}$ \\
\hline \multicolumn{6}{|c|}{ Level of operation of the organization } \\
\hline - Municipal & - & - & - & - & $\mathrm{x}$ \\
\hline - Local & $\mathrm{x}$ & $\mathrm{x}$ & $\mathrm{x}$ & $\mathrm{x}$ & $\mathrm{x}$ \\
\hline - Regional & $\mathrm{x}$ & $\mathrm{x}$ & $\mathrm{x}$ & $\mathrm{x}$ & $\mathrm{x}$ \\
\hline - National & $\mathrm{x}$ & $\mathrm{x}$ & $\mathrm{X}$ & $\mathrm{x}$ & $\mathrm{x}$ \\
\hline - European & $\mathrm{x}$ & $\mathrm{x}$ & $\mathrm{x}$ & $\mathrm{x}$ & $\mathrm{x}$ \\
\hline - International & $\mathrm{x}$ & $\mathrm{x}$ & $\mathrm{X}$ & - & - \\
\hline \multicolumn{6}{|c|}{ Function of the stakeholder } \\
\hline - Politician & $\mathrm{x}$ & $\mathrm{x}$ & $\mathrm{x}$ & $\mathrm{x}$ & $\mathrm{X}$ \\
\hline $\begin{array}{lcc} & \text { Policy } & \text { makers/ } \\
\text { experts/advisor } & \end{array}$ & $\mathrm{x}$ & $\mathrm{x}$ & $\mathrm{x}$ & $\mathrm{x}$ & $\mathrm{x}$ \\
\hline - Regulators & $\mathrm{x}$ & $\mathrm{x}$ & $\mathrm{x}$ & $\mathrm{x}$ & $\mathrm{X}$ \\
\hline - Practitioners & $\mathrm{x}$ & $\mathrm{x}$ & $\mathrm{X}$ & $\mathrm{x}$ & $\mathrm{x}$ \\
\hline - Technical expert & $\mathrm{x}$ & $\mathrm{x}$ & $\mathrm{x}$ & $\mathrm{x}$ & $\mathrm{x}$ \\
\hline - Advocacy/lobbyists & $\mathrm{x}$ & $\mathrm{x}$ & $\mathrm{X}$ & $\mathrm{X}$ & $\mathrm{x}$ \\
\hline - General public & $\mathrm{x}$ & $\mathrm{x}$ & $\mathrm{x}$ & $\mathrm{x}$ & $\mathrm{x}$ \\
\hline - Other & $\mathrm{x}$ & $\mathrm{x}$ & $\mathrm{X}$ & $\mathrm{X}$ & $\mathrm{x}$ \\
\hline \multicolumn{6}{|l|}{ Sector } \\
\hline - Water & $\mathrm{x}$ & $\mathrm{x}$ & $\mathrm{X}$ & $\mathrm{X}$ & $\mathrm{X}$ \\
\hline - Infrastructure & $\mathrm{x}$ & $\mathrm{x}$ & $\mathrm{X}$ & $\mathrm{x}$ & $\mathrm{x}$ \\
\hline - Energy & $\mathrm{x}$ & $\mathrm{x}$ & $\mathrm{x}$ & $\mathrm{x}$ & $\mathrm{x}$ \\
\hline - Finance/Insurance & $\mathrm{X}$ & $\mathrm{x}$ & $\mathrm{X}$ & $\mathrm{X}$ & $\mathrm{x}$ \\
\hline - Agriculture & $\mathrm{x}$ & $\mathrm{x}$ & $\mathrm{x}$ & - & $\mathrm{x}$ \\
\hline - Food \& Nutrition & - & - & $\mathrm{X}$ & $\mathrm{X}$ & $\mathrm{x}$ \\
\hline -Whisky & - & - & $\mathrm{X}$ & - & - \\
\hline - Forestry & - & $\mathrm{x}$ & $\mathrm{X}$ & - & $\mathrm{x}$ \\
\hline $\begin{array}{l}\text { - Biodiversity } \\
\text { conservation }\end{array}$ & - & $\mathrm{x}$ & - & $\mathrm{x}$ & - \\
\hline - Tourism & - & - & $\mathrm{x}$ & - & - \\
\hline - Health & - & $\mathrm{x}$ & $\mathrm{x}$ & $\mathrm{x}$ & $\mathrm{x}$ \\
\hline $\begin{array}{l}\text { - Land use/land use } \\
\text { management }\end{array}$ & - & $\mathrm{x}$ & $x$ & $\mathrm{x}$ & $\mathrm{x}$ \\
\hline - Land owners & - & - & $\mathrm{x}$ & - & - \\
\hline - Trade & $\mathrm{x}$ & - & - & - & - \\
\hline - Security & $\mathrm{x}$ & $\mathrm{x}$ & - & $\mathrm{x}$ & $\mathrm{X}$ \\
\hline - Migration & $\mathrm{x}$ & - & - & $\mathrm{x}$ & - \\
\hline - Disaster risk reduction & $\mathrm{x}$ & - & - & - & - \\
\hline - Humanitarian relief & $\mathrm{x}$ & - & - & - & - \\
\hline - Other & $\mathrm{x}$ & $\mathrm{x}$ & $\mathrm{x}$ & $\mathrm{x}$ & $\mathrm{x}$ \\
\hline \multicolumn{6}{|l|}{ Age } \\
\hline - 30 years and under & $\mathrm{x}$ & $\mathrm{X}$ & $\mathrm{x}$ & $\mathrm{x}$ & $\mathrm{x}$ \\
\hline - 30-50 years & $\mathrm{x}$ & $\mathrm{x}$ & $\mathrm{x}$ & $\mathrm{x}$ & $\mathrm{x}$ \\
\hline - 50 years and above & $\mathrm{x}$ & $\mathrm{x}$ & $\mathrm{x}$ & $\mathrm{x}$ & $\mathrm{x}$ \\
\hline \multicolumn{6}{|l|}{ Gender } \\
\hline - female & $\mathrm{x}$ & $\mathrm{x}$ & $\mathrm{x}$ & $\mathrm{x}$ & $\mathrm{X}$ \\
\hline - male & $\mathrm{X}$ & $\mathrm{X}$ & $\mathrm{X}$ & $\mathrm{X}$ & $\mathrm{x}$ \\
\hline
\end{tabular}


Note: $x$ indicates each criterion per case study; dashes indicate non-relevance of the criterion for the case study.

\section{$\underline{\text { Engagement process }}$}

The engagement process was built to meet specific objectives:

- Create draft case-study specific scenario storylines

- Provide quantifiable input to modelling

- Assess the effects of high-end climate change on the scenario storyline

The methodology was built on the "STIR" approach (Gramberger et al. 2015), which aims at maximizing stakeholder knowledge input during a workshop to strengthen co-production between stakeholders and scientists. The process could be summarized in the following way:

\section{Day 1}

Stakeholders started the scenario development process through an interactive identification of driving forces: a long list was created consisting of factors that would have an important influence on the development of the case study until 2100, apart from climate change. After grouping these driving forces into clusters, the most impactful and uncertain were determined through a voting procedure. The stakeholders then conducted an uncertainty analysis on this selection of clusters, determining the key uncertainty for each cluster as well as the polarities.

\section{Day 2}

Four input scenarios, i.e. 'Sustainability', 'Regional Rivalry', 'Inequality' and 'Fossil-fueled Development' were presented individually to the stakeholders.

Following this presentation, the workshop continued with stakeholders mapping the previously identified key uncertainties and their polarities onto the input scenarios, and by developing the main thrust of these four narratives. The second day of the workshop ended with a presentation and discussion of the developed narratives.

\section{Day 3}

The third day, stakeholders, provided with additional comments and feedback, reworked and expanded the narratives developed the previous day. 
Methodology: European SSPs (Eur-SSPs), local European SSPs and Central Asian SSPs: narratives

Modified from Supplementary Material in Pedde et al. (2019)

In this document, we report the sketches of the European SSPs (Eur-SSPs) and local European SSPs. For the full text, we refer to the deliverable 2.2 of the IMPRESSIONS project (Kok and Pedde 2016). The Eur-SSPs and local European SSPs reported below result from the engagement process and are reported here in the form of narratives and key trends.

The SSP narratives and key trends are reported for the following case studies: Europe, Central Asia, Hungary, Iberia and Scotland. For each case study, we omit the SSP2 scenario as it was not developed in the participatory process.

Amongst the key trends for each SSP in each case study, we report the levels of capitals (human, social, manufactured, financial and natural), as indicators of material and immaterial wealth (Porritt 2007). Increases or decreases in 3 time steps $(2040,2070,2100)$ compared to present are qualitatively indicated with "-" or "+" (" $1 \frac{1 / 2}{2}$ " indicate very small changes). For example, " $(0,+,++)$ " means "no change up to 2040 compared to present, increase up to 2070 compared to present, strong increase up to 2100 compared to present" 


\section{Eur-SSP1 Sustainability}

There is a high commitment to achieve sustainable development goals through effective governments and global cooperation, ultimately resulting in less inequality and less resource intensive lifestyles.

The interplay of financial, environmental, and economic crises fuel the feeling that behavior has to change away from an unregulated market-driven economy to a sustainable development path. This puts governments under pressure to take ambitious measures, including stimulating an energy transition towards renewables and facilitating innovative research, accompanied by investments in health, education, and social support. A decrease in conflicts in Europe's Southern and Eastern border regions leads to higher political stability and moderate but steady economic growth in an increasingly equitable Europe. The European Union expands further and participates in new global governance initiatives. Advances in green technologies are further stimulated by international competition leading to a $\mathrm{CO}_{2}$ neutral society by 2050 . By 2100 , Europe is characterized by a high level of sustainabilityoriented political and societal awareness, focusing on renewable energy and low material growth in a strongly regulated but effective multi-level governance structure.

\begin{tabular}{|l|l|}
\hline Key elements & Sustainability \\
\hline Decision-making level & International/EU leader \\
\hline International cooperation & Strong, EU important player \\
\hline Net migration- low in-migration & Low immigration \\
\hline Economic development & Gradual (with hiccups at the beginning) \\
\hline Mobility & No barriers, but movements are limited \\
\hline Social cohesion & High \\
\hline Technology development & High, but not pervasive \\
\hline Quality of Governance & High - focus on sustainability \\
\hline Human health investments & High \\
\hline Education investments & High \\
\hline Environmental respect & High \\
\hline Human capital & Strong increase $(0,+,++)$ \\
\hline Social capital & Strong increase $(0,+,++)$ \\
\hline Manufactured capital & Steady increase $(0,1 / 2+,+)$ \\
\hline Financial capital & Steady increase $(0,1 / 2+,+)$ \\
\hline
\end{tabular}




\section{Eur-SSP3 Regional Rivalry}

Sparked by economic woes in major economies and regional conflict, antagonism between and within regional blocs increases, resulting in the disintegration of social fabric and many countries struggling to maintain living standards.

With the economy gradually picking up, the demand for resources increases, which turns out to be a tipping point for the state of the environment with severe ecosystem failures. The persistence of conflicts and decline in trade also substantially increases energy and food prices, while initiating a massive build-up of the defense sector, which is resource hungry but not resource efficient. Long-term policy planning becomes rare with hardly any money for education, research or innovation. Eventually the EU breaks down, with new regional blocs forming in the north and in the south of Europe, while new alliances with other countries are forged to ensure sufficient energy supply. Social counter-movements temporarily appear but do not take root in a fragmented and divided Europe with strong regional rivalry and conflict. Ultimately, a high-carbon intensive Europe emerges that is not worse off than the rest of the world, but struggles not to become the world's backwater with high inequalities predominantly between but also within countries.

\begin{tabular}{|l|l|}
\hline Key elements & Regional Rivalry \\
\hline Decision-making level & National/Local+ fragmentation \\
\hline International cooperation & Weak \\
\hline Net migration- low in-migration & Outmigration \\
\hline Economic development & Low \\
\hline Mobility & Low \\
\hline Social cohesion & Low EUlhigher within countries \\
\hline Technology development & Low \\
\hline Quality of Governance & Low and ineffective \\
\hline Human health investments & Low \\
\hline Education investments & Low \\
\hline Environmental respect & Low \\
\hline Human capital & Decrease $(0,-,-)$ \\
\hline Social capital & $\begin{array}{l}\text { Increase, then decrease }(0,+, 0) \text {. Increase } \\
\text { because group of people cluster against } \\
\text { others }\end{array}$ \\
\hline Manufactured capital & Decrease $(0,-,-)$ \\
\hline Financial capital & Strong decrease (-,-,--) \\
\hline
\end{tabular}




\section{Eur-SSP4 Inequality}

Globally, power becomes more concentrated in a relatively small political and business elite, accompanied by increasing disparities in economic opportunity, leading to substantial proportions of populations having a low level of development, although Europe becomes an important player in a world full of tensions.

Sparked by the economic crisis and extreme weather events, the EU increases commitment to find innovative solutions to the depletion of natural resources and climate change. In combination with current relatively high levels of social cohesion, energy efficiency and environmental policy-making this initiates a shift towards a high-tech green Europe. This transformation is strongly supported by large businesses that successfully seek collaboration with the increasingly powerful European government. At the same time, however, inequalities are rising because of a number of simultaneously acting factors, including highly unequal investments in education. This leads to a large and widening gap between an internationallyconnected society and a more fragmented collection of lower-income societies that work in a labor intensive, low-tech economy. Technological development has not resulted in reduced energy prices, but has instead established an oligarchy of green business developers that control energy supply. By 2100, Europe is an important player in a world full of tensions, but with growing inequalities across and within European countries.

\begin{tabular}{|l|l|}
\hline Key elements & Inequality \\
\hline Decision-making level & $\begin{array}{l}\text { International / Europe leader on the global } \\
\text { scale }\end{array}$ \\
\hline International cooperation & Strong, EU important player \\
\hline Net migration- low in-migration & Selected immigration \\
\hline Economic development & High \\
\hline Mobility & High \\
\hline Social cohesion & Low \\
\hline Technology development & $\begin{array}{l}\text { High in some areas; low in labor intensive } \\
\text { areas }\end{array}$ \\
\hline Quality of Governance & High and effective \\
\hline Human health investments & High for elites \\
\hline Education investments & High for elites \\
\hline Environmental respect & High in pockets \\
\hline Human capital & $\begin{array}{l}\text { Decrease and then increase }(0,-, 0) \text {. Middle } \\
\text { class re-emerges }\end{array}$ \\
\hline Social capital & Decrease and then increase $(0,-, 0)$. \\
\hline Manufactured capital & Increase $(0,+,+)$. Depends on sector \\
\hline Financial capital & $\begin{array}{l}\text { Strong increase }(0,++,++) \text { with saturation } \\
\text { after 2050. }\end{array}$ \\
\hline
\end{tabular}




\section{Eur-SSP5 Fossil-fueled Development}

People in this world place increasing faith in competitive markets, innovation and participatory societies to produce rapid technological progress and development of human capital as the path to sustainable development. A lack of environmental concern leads to the exploitation of abundant fossil fuel resources.

Global markets are increasingly integrated, with interventions focused on removing institutional barriers. There are also strong investments in health, education, and institutions to enhance human and social capital. The push for economic and social development is coupled with the exploitation of abundant fossil fuel resources, including large-scale extraction of shale gas. This further stimulates economic wealth, part of which is used to stimulate the development of (green) technologies. Europe regains its leading position in the global economy. Faith is strong in the ability to effectively manage social and ecological systems, including by geo-engineering. Population across all societal classes adopts a very energy intensive lifestyle. The environment degrades, but the majority of the population is unaware because of successful technological innovation. Towards 2100, the environment is locally seriously degraded as non-renewables are further exploited, which eventually results in a slow re-emergence of investments in renewables.

\begin{tabular}{|l|l|}
\hline Key elements & Fossil-fueled Development \\
\hline Decision-making level & $\begin{array}{l}\text { International/EU not a leader on the global } \\
\text { scale }\end{array}$ \\
\hline International cooperation & Strong (trade) \\
\hline Net migration- low in-migration & High to cities and from poorer countries \\
\hline Economic development & High \\
\hline Mobility & High \\
\hline Social cohesion & High \\
\hline Technology development & Strong and crucial \\
\hline Quality of Governance & High - focus on businesses \\
\hline Human health investments & High \\
\hline Education investments & High \\
\hline Environmental respect & Low, but high NIMBY \\
\hline Human capital & Strong increase $\left(1,11 \frac{1}{2}+,++\right)$ \\
\hline Social capital & Strong increase $\left(1,11 \frac{1}{+}+,++\right)$ \\
\hline Manufactured capital & Strong increase $(1,11 / 2+,++)$ \\
\hline Financial capital & Strong increase $(1 / 2+,+,++)$ \\
\hline
\end{tabular}




\section{Central Asian SSP1 - Utopistan}

This scenario is characterized by cooperation between nations in the region and between external actors. Underpinning this cooperation is a distinct Central Asian identity, based on a set of common values and shared lifestyles. The cooperation is ensured by both with topdown and bottom-up initiatives. Firstly, with diversification of resources and energy dependency in the region, which stabilizes Central Asia by decreasing differences between oligarchic interests. Secondly, the region is characterized by an increased attention for common traditional values, which leads to a shift towards sustainability also at more individual level. Countries start to collaborate effectively thanks to the establishment of an effective supervisory intergovernmental body in key common policy areas such as energy diversification, water policy and food production. Population grows steadily. Thanks to effective long-term oriented governance, larger shares of the population have access to resources and global markets. Additionally, people actively participate in the political life, where regional identity is increasingly important and brings people together.

\begin{tabular}{|l|l|}
\hline Key elements & Utopistan \\
\hline Decision-making level & International \\
\hline International cooperation & Strong \\
\hline Net migration- low in-migration & Low immigration \\
\hline Economic development & Fast \\
\hline Mobility & No barriers, but movements are limited \\
\hline Social cohesion & High \\
\hline Technology development & High \\
\hline Quality of Governance & High - focus on community \\
\hline Human health investments & High \\
\hline Education investments & High \\
\hline Environmental respect & High \\
\hline Human capital & Strong increase $(+,+++,+++)$ \\
\hline Social capital & Strong increase $(+,+++,+++)$ \\
\hline Manufactured capital & Strong increase $(+++,++,++)$ \\
\hline Financial capital & Steady increase $(0,0,+)$ \\
\hline
\end{tabular}




\section{Central Asian SSP3 - Regional Rivalry}

This scenario is characterized by rivalry between nations in the region and between external actors. There is strong competition for the resources (water, hydropower, uranium, as well as oil and gas and population) in the region. At first there is strong competition for resources within the region accompanied by "exclusive" economic development. This leads to increasing rivalry between groups in society and a build-up of tension and instability. As competition within the region becomes stronger, the system becomes more and more exclusive with restrictions and controls introduced to maintain the system. Ultimately, the tensions are so large that a breakdown occurs and chaos ensues. External actors then step in to ensure their continued access to the resources of the region. The region is stabilized through the influence of the external actors but again the spiral of competition leading to tensions builds up; this time the competition is between the external actors. Again a breaking point is reached and chaos ensues until 2100. Technology development is low in this scenario. Low technology uptake and low investment continues. Agricultural yields remain far below potential. Soil quality deteriorates through bad irrigation practices. Low investment is one of the drivers for increased competition by reducing the 'available' resources, in particular water.

\begin{tabular}{|l|l|}
\hline Key elements & Regional Rivalry \\
\hline Decision-making level & National/Local+ fragmentation \\
\hline International cooperation & Weak and temporary \\
\hline Net migration- low in-migration & $\begin{array}{l}\text { Strong outmigration and Influx of Chinese } \\
\text { workers from 2040 }\end{array}$ \\
\hline Economic development & Low \\
\hline Mobility & Low \\
\hline Social cohesion & Low \\
\hline Technology development & Low \\
\hline Quality of Governance & Low and ineffective \\
\hline Human health investments & Low \\
\hline Education investments & Low \\
\hline Environmental respect & Low \\
\hline Human capital & Strong decrease $(-,--,---)$ \\
\hline Social capital & Strong decrease $(-,--,---)$ \\
\hline Manufactured capital & Decrease $(0,0,--)$ \\
\hline Financial capital & Strong decrease $(-,-,---)$ \\
\hline
\end{tabular}




\section{Central Asian SSP4 - A Game of Elites}

This scenario is characterized by large and growing inequalities particularly within countries, with a powerful elite established in all countries of Central Asia. These strong and connected elites ensure a high level of stability within and across countries through international connections and collaborations. At the same time, they actively pursue an increase of inequalities by suppressing the majority of the population. The elite is furthermore responsible for effective management of migratory fluxes with China and Russia; establishment of common environmental standards across Central Asia; cross-regional cooperation related to infrastructural projects; water management; and exploitation of natural resources. The large majority of the population ('the masses') are kept quiet, but not happy. Many services (health, education, welfare, housing) are kept at minimum acceptable levels, all of which become largely privatized. Towards 2100 , a new religion emerges and which is channeled by the elite, thus successfully decreasing the chance of uprising of the masses.

\begin{tabular}{|l|l|}
\hline Key elements & Game of Elites \\
\hline Decision-making level & International elite \\
\hline International cooperation & Strong \\
\hline Net migration- low in-migration & Selected immigration of Chinese migrants \\
\hline Economic development & High \\
\hline Mobility & High \\
\hline Social cohesion & Low \\
\hline Technology development & $\begin{array}{l}\text { High in some areas; low in labor intensive } \\
\text { areas }\end{array}$ \\
\hline Quality of Governance & High and effective \\
\hline Human health investments & High for elites \\
\hline Education investments & High for elites \\
\hline Environmental respect & High in pockets \\
\hline Human capital & Decrease $(-,-,--)$. \\
\hline Social capital & Strong decrease $(-,--,--)$. \\
\hline Manufactured capital & Decrease $(-,-,-)$ \\
\hline Natural capital & Strong decrease $(--,--,--)$ \\
\hline
\end{tabular}




\section{Central Asian SSP5 - Fossil-fueled Development}

The global scene is characterized by a positive attitude to competitive markets, innovation and participatory societies to produce rapid technological progress and development of society. As a result the economic development is generally good and international trade is intensified. Partly this is driven by exploitation of fossil fuel resources. There is also a lack of environmental concerns in the world and the life style is 'globalized' with high material consumption. The implementation of the Sustainable Development Goals (SDGs) has been relatively successful with regard to reducing inequality between countries, but less successful with regard to environmental issues. Also in Central Asia, there is a competitive economic development largely based on the fossil fuel industry. The region experiences a boom and there is an inflow of investments and people, partly reinforced by an international development of increased international mobility and opening of labor markets. Also the agricultural sector has seen a good development of its productivity, partly due to improved technologies within this sector. However, the environment in Central Asia pays a high price for the development, and governments mainly focus collaboration on issues that are of importance for the economic development.

\begin{tabular}{|l|l|}
\hline Key elements & Fossil-fueled Development \\
\hline Decision-making level & International \\
\hline International cooperation & Strong (trade and policy) \\
\hline Net migration- low in-migration & $\begin{array}{l}\text { High immigration especially from young } \\
\text { educated people }\end{array}$ \\
\hline Economic development & High \\
\hline Mobility & High \\
\hline Social cohesion & High \\
\hline Technology development & Strong \\
\hline Quality of Governance & High - focus on businesses \\
\hline Human health investments & High \\
\hline Education investments & High \\
\hline Environmental respect & Low, but high NIMBY \\
\hline Human capital & Strong increase $(+,++,++)$ \\
\hline Social capital & Strong increase $(+,++,++)$ \\
\hline Manufactured capital & Strong increase $(+,++,++)$ \\
\hline Natural capital & Decrease $(--,-,-)$ \\
\hline
\end{tabular}




\section{Hungarian SSP1 - Rózsaszin álom}

Triggered by changing public opinion on current economic and demographic problems, local governments take the initiative to invest in services. This results in the local increase of skills and good practices: Veszprém becomes a knowledge center and Szekszárd turns to sustainable agricultural practices. New generation of policy-makers come from local communes and represent the will of people. Because of more transparency and accountability of politicians, corruption decreases. This leads also to an economic shift in many sectors, whereby technology development and high-value exports become the new backbone of the Hungarian economy. International cooperation is strong also thanks to stable neighboring countries and decrease in migration. Emigration and birth rates also stabilize. Hungary in 2100 is a fully sustainable, financially healthy and safe country.

\begin{tabular}{|l|l|}
\hline Key elements & Hungarian SSP1 - Rózsaszin álom \\
\hline Decision-making level & $\begin{array}{l}\text { Multilevel - development model upscaled from local to } \\
\text { national }\end{array}$ \\
\hline International cooperation & Strong, EU important player \\
\hline Net migration- low in-migration & Moderate immigration - reverted brain drain \\
\hline Economic development & Gradual \\
\hline Mobility & No barriers, but movements are limited \\
\hline Social cohesion & High \\
\hline Technology development & High - focus on renewable and re-use \\
\hline Quality of Governance & High - focus on sustainability \\
\hline Human health investments & High \\
\hline Education investments & High \\
\hline Environmental respect & High \\
\hline Human capital & Increase and levelling $(++,++,++)$ (gets high soon) \\
\hline Social capital & Increase and levelling $(++,++,++)$ (gets high soon) \\
\hline Manufactured capital & $0,-,-$ \\
\hline Natural capital & $0,+,+$ \\
\hline
\end{tabular}




\section{Hungarian SSP3 - Regional Rivalry}

In the context of increased geopolitical instability and higher energy prices, the Hungarian government shifts its budget away from environmental and social services towards industrial development and defense. However, stalling wages, low resources and unemployment trigger social tensions and brain drain. The government responds with authoritarian measures, further decreasing social services and implementing fossil-fuel subsidy schemes to keep prices artificially low. Poverty increases and people move out of cities: urban and rural ghettos develop. People try to become self-sufficient by re-learning old practices. By 2100, Hungary is affected by energy shortages: large-scale agricultural and urbanization are halted. Because of increased migration, a new multicultural society emerges.

\begin{tabular}{|l|l|}
\hline Key elements & Hungarian SSP3 - Regional Rivalry \\
\hline Decision-making level & National \\
\hline International cooperation & Weak - conflict \\
\hline Net migration- low in-migration & Brain drain - increased immigration \\
\hline Economic development & Low \\
\hline Mobility & Low - people move to ghettoes \\
\hline Social cohesion & Low \\
\hline Technology development & Low \\
\hline Quality of Governance & Low and ineffective \\
\hline Human health investments & Low \\
\hline Education investments & Low \\
\hline Environmental respect & Low \\
\hline Human capital & Decrease but flattening due to self-reliance $(0,-,-)$ \\
\hline Social capital & $\begin{array}{l}(+,-,-) \text { increases due to crises, decreases due to } \\
\text { institutions }\end{array}$ \\
\hline Manufactured capital & $(+,-,--)$ \\
\hline Natural capital & $\begin{array}{l}\text { Decrease }- \text { some flattening due to reduced input use and } \\
\text { pressure (-,--,-) }\end{array}$ \\
\hline
\end{tabular}




\section{Hungarian SSP4 - Inequality}

The direction of tender systems strengthens a power system leading to concentration of power and landownership in the hands of few. With corruption and tensions on the rise, new elections promise change but fail: new leadership brings stability but strengthens the power of elites. The EU is complacent. A centralized Hungary stabilizes borders and supplied cheap (but low educated) labor force. Health and education services are minimal and the state prefer to manage crises rather than prevent. Besides an industrialized food production system, haven-nots self-organize even if life of the majority is still a struggle, with a controlled media and education system. With growing hunger riots, the elites show flexibility to avoid revolts (thawing of dictatorship) with a new charismatic leader. People live in a very unequal world but they are happy with what they have.

\begin{tabular}{|l|l|}
\hline Key elements & Hungarian SSP4 - Inequality \\
\hline Decision-making level & State - Europe \\
\hline International cooperation & Strong for elites \\
\hline Net migration- low in-migration & First high immigration, then controlled \\
\hline Economic development & Medium-high \\
\hline Mobility & High for elite \\
\hline Social cohesion & Low - high for have-nots \\
\hline Technology development & $\begin{array}{l}\text { High in some areas; low in labor intensive } \\
\text { areas }\end{array}$ \\
\hline Quality of Governance & Effective (stability) \\
\hline Human health investments & Low \\
\hline Education investments & Low \\
\hline Environmental respect & High in pockets \\
\hline Human capital & $(---,--,-)$ \\
\hline Social capital & $(0,--,-)$ \\
\hline Manufactured capital & $(-,--,-)$ \\
\hline Natural capital & $(--,-, 0)$ \\
\hline
\end{tabular}




\section{Hungarian SSP5 - Pató Pál Ur}

Lifestyle in Hungary is increasingly coupled with increased consumption, less social interactions and pervasive technology. Higher energy demand is met with readily available fossil fuels and little investments on new energy or infrastructure. An exclusive development model sets up, with rising corruption. However, popularity is high because of effective crises management and welfare spending. Even if education is stratified, with high mobility for the rich, all layers of society have a decent energy-hungry lifestyle. Technology can fix temporarily the wide spreading environmental and health degradation until the system collapse. Population decimates. The increasing awareness for change leads to a rebirth of communities. Hungary returns on the bumpy path towards a post fossil fuel era that was abandoned decades before.

\begin{tabular}{|l|l|}
\hline Key elements & Hungarian SSP5 - Pató Pál Úr \\
\hline Decision-making level & International/national \\
\hline International cooperation & Strong (trade) \\
\hline Net migration- low in-migration & High \\
\hline Economic development & High, until collapse \\
\hline Mobility & High \\
\hline Social cohesion & Low, then higher \\
\hline Technology development & Strong and crucial \\
\hline Quality of Governance & $\begin{array}{l}\text { High }- \text { focus on national level and } \\
\text { industries }\end{array}$ \\
\hline Human health investments & High - welfare system \\
\hline Education investments & High - welfare system \\
\hline Environmental respect & Low \\
\hline Human capital & $(-,-,-)$ \\
\hline Social capital & $(-,-,-)$, \\
\hline Manufactured capital & $(+,++,++)$ \\
\hline Natural capital & $(-,--,--)$ \\
\hline
\end{tabular}




\section{Iberia SSP1 - Sustainability}

Triggered by continuing and growing social participation in environmental, social, and economic issues and fueled by a European social-oriented political framework, Iberia embraces a path towards a new development model. Initially at slow pace, but increasing rapidly and supported by socially and environmentally sustainable policy making, a fundamental change is achieved towards boosting education, innovation, job opportunities in the green sectors (renewables and reuse of materials), and eventually green technologies. Because of the strengthening of the democratic governance structures, globalization is no longer opposed to local sustainability, but on the contrary, positive sustainable development synergies are being created. This leads also to an economic shift in many sectors, whereby technology development and high-value exports become the new backbone of the Iberian economy. By 2100, the new decision-making culture and practice culminates in the new development model for the Iberian countries. This model encourages broad public participation, institutional collaboration and includes a harmonic integration of health, social, economic, political and environmental sectors.

\begin{tabular}{|l|l|}
\hline Key elements & Iberia SSP1 - Sustainability \\
\hline Decision-making level & $\begin{array}{l}\text { International - both bottom-up and top- } \\
\text { down }\end{array}$ \\
\hline International cooperation & Strong, EU important player \\
\hline Net migration- low in-migration & Moderate immigration \\
\hline Economic development & Gradual \\
\hline Mobility & No barriers, but movements are limited \\
\hline Social cohesion & High \\
\hline Technology development & High - focus on renewable and re-use \\
\hline Quality of Governance & High - focus on sustainability \\
\hline Human health investments & High \\
\hline Education investments & High \\
\hline Environmental respect & High \\
\hline Human capital &,,+++++++ \\
\hline Social capital &,,++++++++ \\
\hline Manufactured capital &,,-+++ \\
\hline Natural capital &,,-+++++ \\
\hline
\end{tabular}




\section{Iberia SSP3 - Regional Rivalry}

Short-lived governments lead to a fragmentation of the social and economic fabric in Iberia. In 2030 Catalonia gains independence, which is later followed by other regions both in Iberia and in other Mediterranean countries. To counteract economic crises, the Southern countries unite in a separate Union, the 'Club Med'. Continued environmental and economic problems increase social tensions and social inequalities, which in turn negatively affect tourism. By the 2060s four countries have come to exist in Iberia: Portugal, Spain, Catalonia and the Basque Country, with strong borders between them. Over time, conflicts escalate although war over water and other scarce resources is prevented. By 2100, a deserted inland rural Iberia remains and this produces a large divide even further than with the rest of Europe. Continuous conflicts across multiple countries which experiment such similar disintegration processes occur elsewhere and this limit cooperation within Club Med and with other international power blocs.

\begin{tabular}{|l|l|}
\hline Key elements & Iberia SSP3 - Regional Rivalry \\
\hline Decision-making level & National/Local+ fragmentation \\
\hline International cooperation & Weak \\
\hline Net migration- low in-migration & Outmigration \\
\hline Economic development & Low \\
\hline Mobility & Low \\
\hline Social cohesion & Low within and across Iberia \\
\hline Technology development & Low \\
\hline Quality of Governance & Low and ineffective \\
\hline Human health investments & Low \\
\hline Education investments & Low \\
\hline Environmental respect & Low \\
\hline Human capital &,,------- \\
\hline Social capital &,,------- and $1 / 2$ \\
\hline Manufactured capital &,,-------- \\
\hline Natural capital &,,------- \\
\hline
\end{tabular}




\section{Iberia SSP4 - Inequality}

Economic challenges and environmental accidents are exacerbated by new European and global crises, which leads to an increased migration from Northern Africa and the Middle East. In Iberia, unemployment rises to record levels, this eventually results in social unrest and massive protests. Social stratification intensifies with strong high-income elites and a divided large lower class, bringing about strong tensions within and between social classes. This unstable social situation escalates in the 2040s, and lead to a shift in the political system. New governments establish an oligarchical system with power and money gradually centralized and controlled by an elite of a few companies and central governments. The political and industrial elite successfully implements a strategy of "subtle" enforcement of inequality through education and keeping people busy on low skilled tasks, with low future expectations. To their benefit, the elite invests in solar and wind energy, eventually becoming a market leader.

\begin{tabular}{|l|l|}
\hline Key elements & Iberia SSP4 - Inequality \\
\hline Decision-making level & International / Europe \\
\hline International cooperation & Strong, Iberia strong player in EU \\
\hline Net migration- low in-migration & First high immigration, then controlled \\
\hline Economic development & High \\
\hline Mobility & High \\
\hline Social cohesion & Low \\
\hline Technology development & $\begin{array}{l}\text { High in some areas; low in labor intensive } \\
\text { areas }\end{array}$ \\
\hline Quality of Governance & High and effective \\
\hline Human health investments & High for elites \\
\hline Education investments & High for elites \\
\hline Environmental respect & High in pockets \\
\hline Human capital &,,+--1 and $1 / 2$ \\
\hline Social capital & $+, 0,-$ \\
\hline Manufactured capital & $1 / 2+,+,++$ \\
\hline Natural capital &,,+++++ \\
\hline
\end{tabular}




\section{Iberia SSP5 - Fossil-fueled Development}

The burst of the financial bubble increases the need for social aid and subsidies for Iberia, which is facilitated by an increasing economic surplus in the north of Europe. Crucial is the establishment of a connection of electricity networks that increase access to external (fossil) resources. Iberia is part of this network and located strategically in the energy nexus. Iberia also starts exploiting its own resources, while intensifying agriculture and forestry. In the 2040s, environmental problems occur that are combatted with successful technological solutions. The accompanying environmental destruction goes by unnoticed as most people live in the cities, where water, food, and energy supply are secured. By 2060, Iberia totally depends on technology, fossil fuels, and investments of large companies. Ultimately, a number of environmental disasters lead to an increased awareness across Iberia that technology can no longer sustain agricultural production. The outlook is uncertain as the fossil-fuel based development model collapses and business opportunities decrease.

\begin{tabular}{|l|l|}
\hline Key elements & Iberia SSP5 - Fossil-fueled Development \\
\hline Decision-making level & $\begin{array}{l}\text { International/EU not a leader on the global } \\
\text { scale }\end{array}$ \\
\hline International cooperation & Strong (trade) \\
\hline Net migration- low in-migration & High to cities and from poorer countries \\
\hline Economic development & High, until collapse \\
\hline Mobility & High \\
\hline Social cohesion & Medium \\
\hline Technology development & Strong and crucial \\
\hline Quality of Governance & Focus on businesses \\
\hline Human health investments & High (private), then low \\
\hline Education investments & High (private), then low \\
\hline Environmental respect & Low \\
\hline Human capital &,,+++++++ \\
\hline Social capital &,,++-- \\
\hline Manufactured capital &,,++++++++ \\
\hline Natural capital &,,------ \\
\hline
\end{tabular}




\section{Scottish SSP1 - Mactopia}

Through increased societal involvement policy and effective governance, Scotland achieves the transition towards a sustainable and equitable society by 2040. This transition comes within the context of positive economic development and a further devolution from the UK. Scotland has stronger ties with other like-minded countries both within and outside the EU. More income is also generated from the export of surplus water and is invested in social and environmental policies. The shift towards a green (but highly taxed) economy increases tax evasion and resource smuggling. In addition, some social unrest develops as a result of the increase in both unskilled and highly skilled migrants, especially from the rest of the UK. These problems are, however, limited due to high government presence (e.g. with social assimilation programs). By 2070-2100, Scotland has become more aware of national security issues, but the core values of social and environmental sustainability and equity are dominant. Thus the country remains open to trade by consolidating healthy trade relationships with rich countries, as well as helping with the (economic) development of poor countries. The country has grown a bit less than business-as-usual, but unemployment and homeless people are now something of the past.

\begin{tabular}{|l|l|}
\hline Key elements & SSP1 - Mactopia \\
\hline Decision-making level & Multilevel and communitarianism \\
\hline International cooperation & Strong with like-minded countries and BRICS \\
\hline Net migration- low in-migration & High immigration \\
\hline Economic development & Steady but somewhat slow \\
\hline Mobility & No barriers, \\
\hline Social cohesion & High \\
\hline Technology development & High \\
\hline Quality of Governance & High - focus on trade-offs and social inclusiveness \\
\hline Human health investments & High \\
\hline Education investments & High \\
\hline Environmental respect & High \\
\hline Human capital & Strong increase $(+,++,++)$ \\
\hline Social capital & Strong increase $(+,++,++)$ \\
\hline Manufactured capital & Increase $(+,+,+)$ \\
\hline Financial capital & Steady increase $(+,+,++)$ \\
\hline
\end{tabular}




\section{Scottish SSP3 - Mad Max}

On-going conflicts, political instability and demographic issues in other countries are drivers for increased resource issues and migration to Scotland. Because of increased pressure on resource exploitation, investors buy up land and access to water leading to volatile markets. More and more people have problems buying land but also food and water. This leads to a society with less solidarity. Energy becomes increasingly valuable and the government sells energy to the highest bidders. These are multinationals who also own large portions of land, control the scarce water and food supplies and determine the consistently high pricing of essential goods and commodities. Fragmentation of society leads to more sectarianism. Conflicts between Catholics and Protestants are rampant, especially in the small mining communities in the Highlands. By 2040 the EU breaks down and suffers from social unrest and an economic and energy crisis. In Scotland, a survival from day-to-day, "getting the sandbags out" type of mentality prevails over a long-term structural approach, especially for the Have-nots. The Haves on the other hand are preoccupied with securing their fortunes and the few remaining resources. By 2070-2100, we reach a balance, where both the Haves and Have-nots realize they have to organize themselves: the Haves to protect themselves and their property, the Have-nots to survive. These unions originate out of necessity. However, conflict within these groups is also common. There is no, or very limited contact between the different strata. The poorer Scots work for the richer Scots, but that is the only interaction between them. The whole society has learned to live with less.

\begin{tabular}{|l|l|}
\hline Key elements & SSP3 - Mad Max \\
\hline Decision-making level & Corporate and clan level \\
\hline International cooperation & Weak \\
\hline Net migration- low in-migration & High immigration at the beginning \\
\hline Economic development & Low \\
\hline Mobility & Very low \\
\hline Social cohesion & Low between strata, higher within strata \\
\hline Technology development & Low \\
\hline Quality of Governance & $\begin{array}{l}\text { Low and ineffective at national level (short- } \\
\text { term })\end{array}$ \\
\hline Human health investments & Low \\
\hline Education investments & Low \\
\hline Environmental respect & Low \\
\hline Human capital & Decrease $(-,-,-)$ \\
\hline Social capital & Decrease $(-, 1 / 2-, 1 / 2-)$ \\
\hline Manufactured capital & Decrease $(1 / 2-,-,--)$ \\
\hline Financial capital & Strong decrease $(-, 1$ and $1 / 2-,-)$ \\
\hline
\end{tabular}




\section{Scottish SSP4 - Tartan Spring}

The strong middle class and present prosperity pave the way for technological innovation which leads to more efficient use of resources. A whole new generation of highly educated young people takes the lead. To capture the full potential of all these technological developments, the Scottish government decides to open resource access to the private sector and to establish liberal market structures. As a result, by 2040 the influence of the private sector in Scotland has become very strong. Economic growth becomes the fundament of Scottish nationalism and of political independence is achieved in 2040. The middle class favors further deregulation and cuts in public spending, spearheaded by the economic growth. An unwanted consequence is the disappearance of welfare measures and more public GDP spent on overseas conflicts to secure ownership of access to resources. With more income from resources going to multinationals and little welfare, disparity between the poor and the wealthy in Scotland is more pronounced. This disparity further increases because technological innovation makes it possible to eliminate jobs and manpower. Those that have a job still benefit from privately organized health care schemes, but a large part of the workforce services the super-rich and has only limited social security, barely enough for a decent life. By 2070 people realize that is not enough to live in a rich country which lacks sustainability and accountability of governance. Strikes and uprising become more frequent and violent. Scotland enters turbulent times.

\begin{tabular}{|l|l|}
\hline Key elements & SSP4 - Tartan Spring \\
\hline Decision-making level & National/Multinationals \\
\hline International cooperation & Strong, EU important player \\
\hline Net migration- low in-migration & High migration \\
\hline Economic development & High \\
\hline Mobility & Low \\
\hline Social cohesion & Low \\
\hline Technology development & High \\
\hline Quality of Governance & Ineffective \\
\hline Human health investments & High and then private (exclusive) \\
\hline Education investments & High and then private (exclusive) \\
\hline Environmental respect & Low \\
\hline Human capital & Decrease and then increase $(+, 0,-)$. \\
\hline Social capital & $\begin{array}{l}\text { Many small up and downs between } 2050 \text { and } 2100 \\
(1 / 2+, 0,0)\end{array}$ \\
\hline Manufactured capital & Increase $(+,+,+)$ \\
\hline Financial capital & Increase then decrease $(1 / 2+,+, 0)$ \\
\hline
\end{tabular}




\section{Scottish SSP5 - Fossil-fueled Development}

A stabilization of the fossil fuel price has allowed for an increased tax on fossil fuels. Because of a concomitant increase of immigrants from outside the EU, the Scottish government invests extra income in health services, social housing and education. The government also invests in the establishment of for-profit publically owned energy companies, such as Statoil and the Scotland Energy Corporation (SEC). At the central level, SEC investment fund has a large stake in fossil fuels and can invest in public services. This means profits stay in Scotland, with SEC paying dividends to each Scottish resident. By 2040, Scottish policy is increasingly driven by technology in many sectors: finance, education (technology university), labor force. Strong devolution has also resulted in 'clantons'. These become more and more powerful alongside public participation, e.g. with innovative internet referenda. The lack of focus in environmental problems, however, starts to have its toll. Some discontent starts to rise among pockets of the population, driven by issues such as 'the last bumblebee in Scotland'. This is initially partly overshadowed by steady economic growth. By 2070 energy and food demands are met and surpassed. On the other hand, environmental degradation reaches a tipping point. Larger shares of the population realize the high costs of geo-engineering, and the increasing economic inefficiency of fossil fuels. As a result, unhappiness about environmental degradation spreads. After a major clean-up undertaken by SEC, a shift towards renewables triggers a change towards a whole new energy system. SEC investments in renewables slowly increase, matching those in fossil fuels by the end of the century.

\begin{tabular}{|l|l|}
\hline Key elements & SSP5 - Fossil-fueled Development \\
\hline Decision-making level & International/national and "clantons" \\
\hline International cooperation & Strong (trade) \\
\hline Net migration- low in-migration & High to cities and from non-EU countries \\
\hline Economic development & High \\
\hline Mobility & High \\
\hline Social cohesion & High \\
\hline Technology development & Strong and crucial \\
\hline Quality of Governance & High - focus on profitable investments \\
\hline Human health investments & High \\
\hline Education investments & High (focus on sciences, engineering and technology) \\
\hline Environmental respect & Low, but high NIMBY \\
\hline Human capital & Increase $(0,+,+)$ \\
\hline Social capital & Decrease $(0,-,-)$. High human but low social capital \\
\hline Manufactured capital & Strong increase $(+,++,++)$ \\
\hline Financial capital & $\begin{array}{l}\text { Strong increase }(+,++,+++) . \text { Faster growth rate than } \\
\text { present }\end{array}$ \\
\hline
\end{tabular}




\section{Results}

The narrative coding was analyzed for three authors. Expert 1 is reported in the Results of the main text. The results from experts 2 and 3 are reported below, in Figures A1 and A2

SSP1

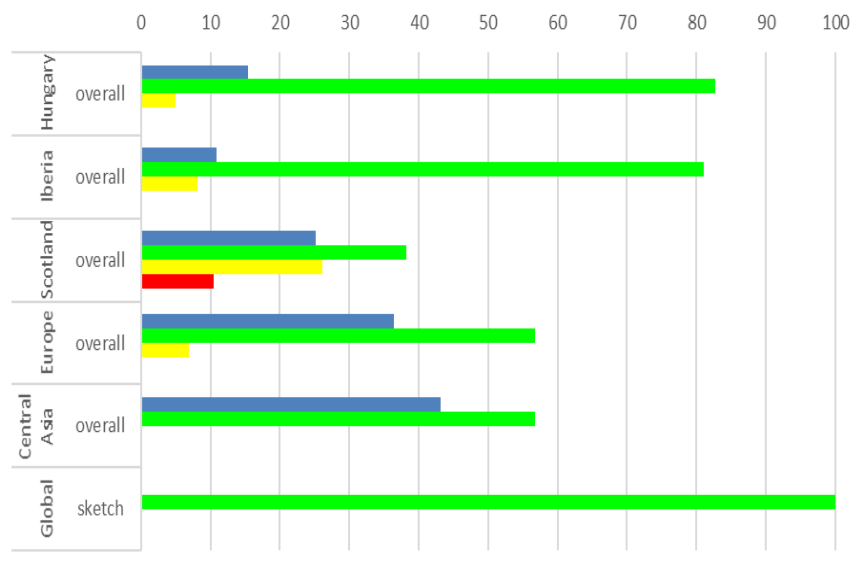

SSP4

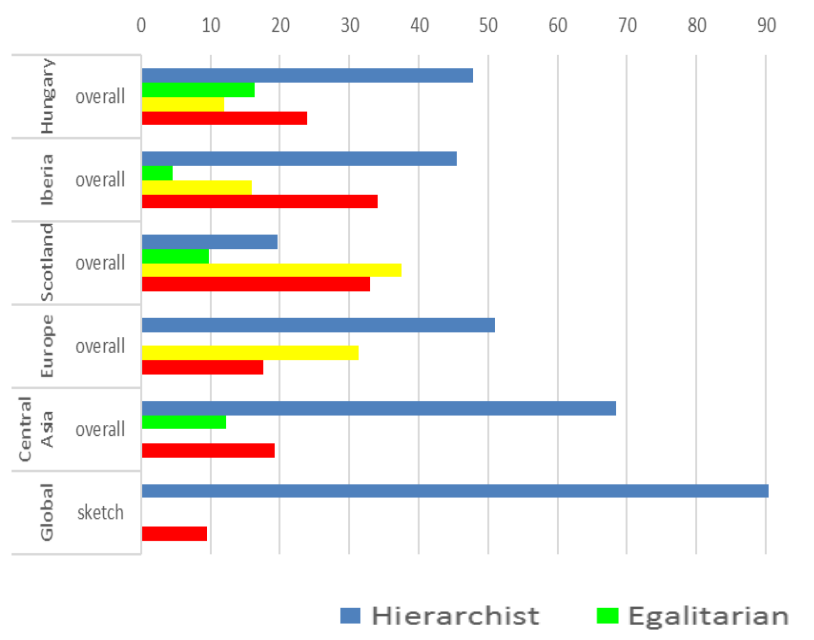

SSP3

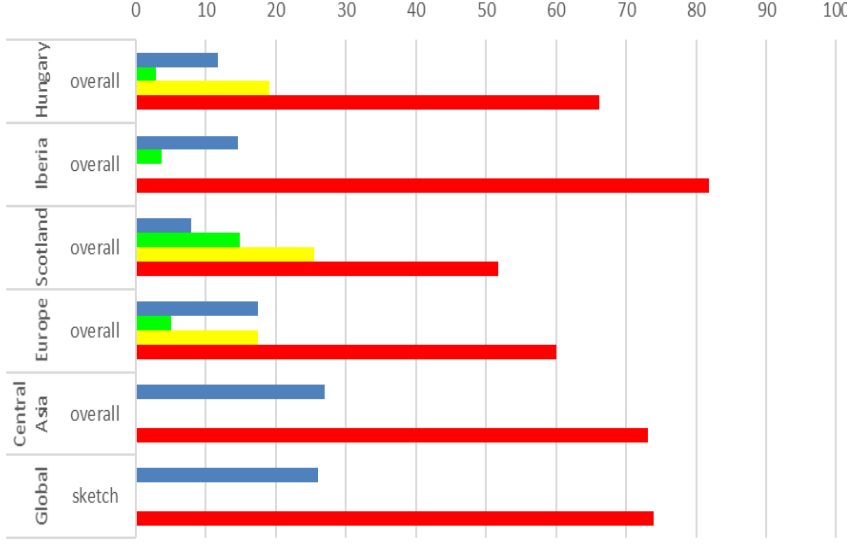

SSP5



Figure A1: Analysis of worldviews (from expert 2) 


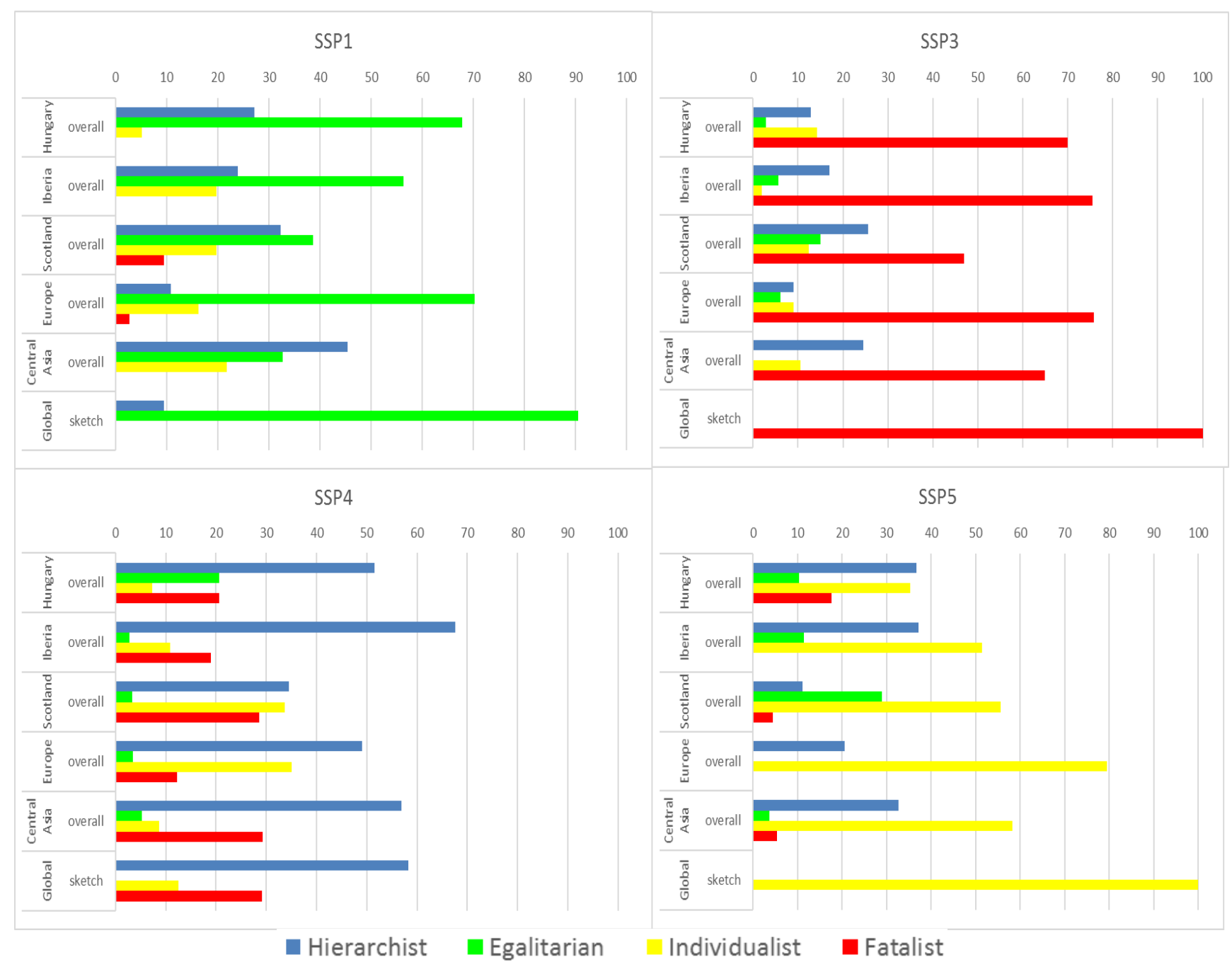

Figure A2: Analysis of worldviews (from expert 3) 


\section{$\underline{\text { References }}$}

Gramberger, M., Zellmer, K., Kok, K., Metzger, M.J. (2015). Stakeholder integrated research (STIR): a new approach tested in climate change adaptation research. Climatic Change 128(34): 201-214.

Kok, K. and S. Pedde (2016). "IMPRESSIONS socio-economic scenarios." IMPRESSIONS project

Pedde, S., Kok, K., Hölscher, K., Frantzeskaki, N., Holman, I., Dunford, R., Smith, A. and Jäger J. (2019). Advancing the use of scenarios to understand society`s capacity to achieve the 1.5 degree target. Global Environmental Change 56: 75-85.

Porritt, J. (2007). The Five Capitals Framework. Capitalism as if the World Matters. London, UK, Earthscan: 137-142. 